University of Nebraska - Lincoln

DigitalCommons@University of Nebraska - Lincoln

\title{
Targeted disruption of the glutaredoxin 1 gene does not sensitize adult mice to tissue injury induced by ischemia/reperfusion and hyperoxia
}

\author{
Ye-Shih Ho \\ Wayne State University, yho@wayne.edu \\ Ye Xiong \\ Wayne State University \\ Dorothy S. Ho \\ Wayne State University \\ Jinping Gao \\ East Tennessee State University \\ Balvin H.L. Chua \\ East Tennessee State University, chuab@xtn.net \\ See next page for additional authors
}

Follow this and additional works at: https://digitalcommons.unl.edu/veterans

Ho, Ye-Shih; Xiong, Ye; Ho, Dorothy S.; Gao, Jinping; Chua, Balvin H.L.; Pai, Harish; and Mieyal, John J., "Targeted disruption of the glutaredoxin 1 gene does not sensitize adult mice to tissue injury induced by ischemia/reperfusion and hyperoxia" (2007). U.S. Department of Veterans Affairs Staff Publications. 40. https://digitalcommons.unl.edu/veterans/40

This Article is brought to you for free and open access by the U.S. Department of Veterans Affairs at DigitalCommons@University of Nebraska - Lincoln. It has been accepted for inclusion in U.S. Department of Veterans Affairs Staff Publications by an authorized administrator of DigitalCommons@University of Nebraska - Lincoln. 


\section{Authors}

Ye-Shih Ho, Ye Xiong, Dorothy S. Ho, Jinping Gao, Balvin H.L. Chua, Harish Pai, and John J. Mieyal 


\author{
Original Contribution
}

\title{
Targeted disruption of the glutaredoxin 1 gene does not sensitize adult mice to tissue injury induced by ischemia/reperfusion and hyperoxia
}

\author{
Ye-Shih Ho ${ }^{\text {a,* }}$, Ye Xiong ${ }^{a}$, Dorothy S. Ho ${ }^{\text {a }}$, Jinping Gao ${ }^{\text {b }}$, Balvin H.L. Chua ${ }^{b}$, \\ Harish Pai ${ }^{\mathrm{c}}$, John J. Mieyal ${ }^{\mathrm{c}}$ \\ a Institute of Environmental Health Sciences and Department of Biochemistry and Molecular Biology, Wayne State University, Detroit, MI 48201, USA \\ ${ }^{\mathrm{b}}$ Department of Pharmacology and Cecile Cox Quillen Laboratory of Geriatric Research, James H. Quillen College of Medicine, East Tennessee State University, \\ and James H. Quillen Veterans Affairs Medical Center, Johnson City, TN 37614, USA \\ ${ }^{\mathrm{c}}$ Department of Pharmacology, School of Medicine, Case Western Reserve University, Cleveland, OH 44106, USA
}

Received 3 May 2007; revised 22 June 2007; accepted 21 July 2007

Available online 6 August 2007

\begin{abstract}
To understand the physiological function of glutaredoxin, a thiotransferase catalyzing the reduction of mixed disulfides of protein and glutathione, we generated a line of knockout mice deficient in the cytosolic glutaredoxin 1 (Grx1). To our surprise, mice deficient in Grx1 were not more susceptible to acute oxidative insults in models of heart and lung injury induced by ischemia/reperfusion and hyperoxia, respectively, suggesting that either changes in S-glutathionylation status of cytosolic proteins are not the major cause of such tissue injury or developmental adaptation in the Glrxl-knockout animals alters the response to oxidative insult. In contrast, mouse embryonic fibroblasts (MEFs) isolated from Grx1-deficient mice displayed an increased vulnerability to diquat and paraquat, but they were not more susceptible to cell death induced by hydrogen peroxide $\left(\mathrm{H}_{2} \mathrm{O}_{2}\right)$ and diamide. A deficiency in Grx1 also sensitized MEFs to protein S-glutathionylation in response to $\mathrm{H}_{2} \mathrm{O}_{2}$ treatment and retarded deglutathionylation of the S-glutathionylated proteins, especially for a single prominent protein band. Additional experiments showed that MEFs lacking Grx 1 were more tolerant to apoptosis induced by tumor necrosis factor $\alpha$ plus actinomycin D. These findings suggest that various oxidants may damage the cells via distinct mechanisms in which the action of Grx1 may or may not be protective and Grx1 may exert its function on specific target proteins.
\end{abstract}

(C) 2007 Elsevier Inc. All rights reserved.

Keywords: Reaction oxygen species; Protein glutathionylation; Thiol oxidation; Cell death; Gene targeting; Free radicals

Reactive oxygen species (ROS) have been shown to participate in the pathogenesis of many human diseases [1]. However, the biochemical mechanisms by which ROS cause cell damage and ultimately organ dysfunction are not completely understood. One of the major cellular targets of ROS is protein.

Abbreviations: ROS, reactive oxygen species; GSH, glutathione; proteinSSG, protein-glutathione mixed disulfides; Grx1, glutaredoxin 1 protein; Glrxl, glutaredoxin 1 gene; Trx, thioredoxin; PBS, phosphate-buffered saline; MEFs, mouse embryonic fibroblasts; BAC, bacterial artificial chromosome; TTC, triphenyltetrazolium chloride; D-PBS, Dulbecco's phosphate-buffered saline; MTT, 3-(4,5-dimethylthiazol-2-yl)-2,5-diphenyl-tetrazolium bromide; diamide, azodicarboxylic acid bis (dimethylamide); diquat, $1,1^{\prime}$-ethylene-2,2' bipyridyldiylium dibromide; paraquat, 1,1'-dimethyl-4,4'-bipyridinium dichloride; TNF $\alpha$, tumor necrosis factor $\alpha$; $\mathrm{AD}$, actinomycin $\mathrm{D}$; LAD, left anterior descending coronary artery.

* Corresponding author. Fax: +1 3135770082

E-mail address: yho@wayne.edu (Y.-S. Ho).
ROS can oxidize both aliphatic and aromatic amino acid residues of proteins [2], leading to irreversible structural changes. Additionally, the cysteine residues of proteins, particularly after ionization to cysteine thiolate anions, are vulnerable to oxidation to form sulfenic acids (-SOH). The cysteine sulfenic acids in proteins are very unstable and can have several fates; they can react readily with vicinal protein thiols or nonprotein thiols, especially glutathione (GSH), to form intra- and interprotein disulfides and mixed disulfides of proteins with GSH (proteinSSG), respectively. Alternatively, in the absence of thiols in close vicinity, they can be further oxidized to cysteine sulfinic $\left(\mathrm{RSO}_{2} \mathrm{H}\right)$ and sulfonic $\left(\mathrm{RSO}_{3} \mathrm{H}\right)$ acids. The chemical changes that result from thiol oxidation can affect the catalytic and/or structural function of a protein.

Remarkably, cells are equipped with various enzyme systems to specifically reduce most of these forms of oxidized thiols. 
Cysteine sulfinic acid is generally thought to represent an irreversible oxidative product of protein thiols that can progress to the sulfonic acid oxidation state. However, recent data have documented an exception, showing that the sulfinic acid moiety in 2-Cys peroxiredoxins in cells under oxidative stress can be reduced by two ATP-dependent reductases, sulfiredoxin and sestrin [3-6].

The other forms of oxidized protein thiols can be reduced by two members of the thiol-disulfide oxidoreductase superfamily, thioredoxin (Trx) and glutaredoxin (Grx), that contain conserved Cys-X-X-Cys motifs and serve as hydrogen donors for ribonucleotide reductase [7]. Although both Trx and Grx exhibit activity in regeneration of oxidatively damaged proteins, further studies have shown that they have different substrate preferences $[8,9]$. Trx has been reported to preferentially reduce protein sulfenic acids as well as intra- and interprotein disulfides. Two isoforms of Trx have been found in mammals, Trx 1 is located in the cytosol and Trx2 in the mitochondria [10,11]; both function in modulation of cellular redox signaling and in defense against oxidant-mediated injury in vitro and in vivo [12].

Grx is believed to play a unique role in the repair of oxidized protein thiols, specifically catalyzing the reduction of proteinSSG $[9,13]$. Because GSH is the most abundant nonprotein thiol in cells (at concentrations from 0.5 to $20 \mathrm{mM}$ ) [14], the majority of protein mixed disulfides formed inside cells under oxidative stress are protein-SSG and to a lesser extent intra- and interprotein disulfides. For the latter two species of protein disulfides, formation of intraprotein disulfides is believed to be more favorable than that of interprotein disulfides in cells under oxidative stress, because the chance of having two thiol groups residing on two proteins in close vicinity is relatively low. The protein-SSG mixed disulfides are reduced efficiently by Grx via a monothiol mechanism involving a nucleophilic double displacement reaction in which GSH serves to recycle the enzyme [15]. Furthermore, previous tissue and cell culture studies have indicated that glutathione-dependent catalysis by Grx accounts for most of the deglutathionylation activity $[16,17]$. Therefore, Grx is believed to play a pivotal role in defense against oxidative stress and in redox regulation of cellular function [13].

Two glutaredoxin (Glrx) genes have been characterized in mammals. The Glrx 1 gene encodes the cytosolic enzyme Grx1 [18]. The second Glrx (Glrx2) gene encodes two proteins as a result of alteration of RNA splicing. One of the Grx2 isoforms is expressed with an $\mathrm{N}$-terminal leader sequence that directs it to the mitochondria, and both have C-terminal sequences that suggest nuclear localization $[19,20]$. As expected, cells overexpressing Grx1 are more resistant to doxorubicin-induced toxicity compared to control cells [21]. In addition, treatment of cultured cerebellar granule neurons with recombinant Grx protein from Escherichia coli prevents cell death induced by dopamine, and the protection seems to be mediated through activation of the Ras/PI3K/Ref-1/Akt/NF-kB pathway [22,23]. This protective mechanism was further elaborated in another study in which Grx1 overexpression was shown to protect $\mathrm{H} 9 \mathrm{c} 2$ cells against toxicity of hydrogen peroxide $\left(\mathrm{H}_{2} \mathrm{O}_{2}\right)$ [24]. Apparently, Grx1 maintains the level of phosphorylated Akt (activated Akt), a general mediator of cellular survival signals, by dissociating the interaction between Akt and protein phosphatase 2A. Interestingly, Grx1 also affects other cellular signaling pathways. Lee and colleagues showed that Grx 1 protects cells against oxidant injury from glucose starvation, probably through binding to the $\mathrm{C}$-terminus of apoptosis signalregulating kinase $1[25,26]$. In addition, a number of studies with a variety of cells in culture have documented a role for Grx 1 in regulation of redox signal transduction [13]. Despite these in vitro studies, the function of Grx1 in vivo has not yet been characterized. In this report, we describe the generation of a line of knockout mice deficient in Grx1, along with tests of the potential physiological consequences of the enzyme deficiency.

\section{Materials and methods}

\section{Targeted disruption of the mouse Glrx1 gene}

Custom polymerase chain reaction screening of a bacterial artificial chromosome (BAC) library carrying strain 129SV mouse genomic DNA was performed by Incyte Genomics (St. Louis, MO, USA) using two pairs of primers derived from the sequence of a mouse cDNA coding for Grx1 (NCBI Accession No. AA239905). Three BAC clones (GS Control Nos. 20424, 20428, and 20429) were identified from the screening. Multiple DNA fragments from BAC clone 20424 were then subcloned into plasmid pKS (Stratagene, La Jolla, CA, USA) and the DNA sequence was determined. The mouse Glrxl gene contains three exons and the protein coding sequence is located in the first two exons (Fig. 1A). Exon 3 codes only for the 3' untranslated sequence of the mRNA. The structure of the mouse Glrxl gene is virtually identical to that of the human gene, except intron 1 of the mouse gene is unusually long$7.2 \mathrm{~kb}$, compared to $1.0 \mathrm{~kb}$ in humans [27].

To construct the targeting vector, the $3.5-\mathrm{kb}$ HindIII DNA fragment containing the $5^{\prime}$ flanking sequence of the mouse Glrxl gene was first inserted into the HindIII site of plasmid pKS with the direction of transcription of the mouse genomic DNA fragment opposite to that of the ampicillin resistance gene (coding for $\beta$-lactamase). The 3.5-kb HindIII DNA fragment was subsequently released from the pKS vector by digestion with enzymes KpnI and XbaI (which are located in the multiple cloning sites of $\mathrm{pKS}$ vector) and cloned into the corresponding sites in plasmid pPNT [28], resulting in plasmid pPNT-5'Glrx1. The plasmid pPNT-5'Glrx1 was digested with KpnI and SalI, blunt-ended by treatment with mung bean nuclease, and then religated. These procedures removed the XhoI site, which was derived from the multiple cloning sites of $\mathrm{pKS}$, from plasmid pPNT-5'Grx 1 to generate plasmid pPNT-5'Glrx 1(-X). To insert the $3^{\prime}$ portion of the mouse Glrxl gene into the targeting vector, the 1.9-kb BamHI DNA fragment containing exon 3 of the mouse Glrxl gene was initially inserted into the BamHI site of plasmid pKS with transcription direction opposite to that of the ampicillin resistance gene. This BamHI DNA fragment was then removed from the $\mathrm{pKS}$ plasmid by digestion with enzymes XhoI and NotI (which sites are located in the multiple cloning sites of pKS vector) and cloned into the corresponding sites in plasmid 


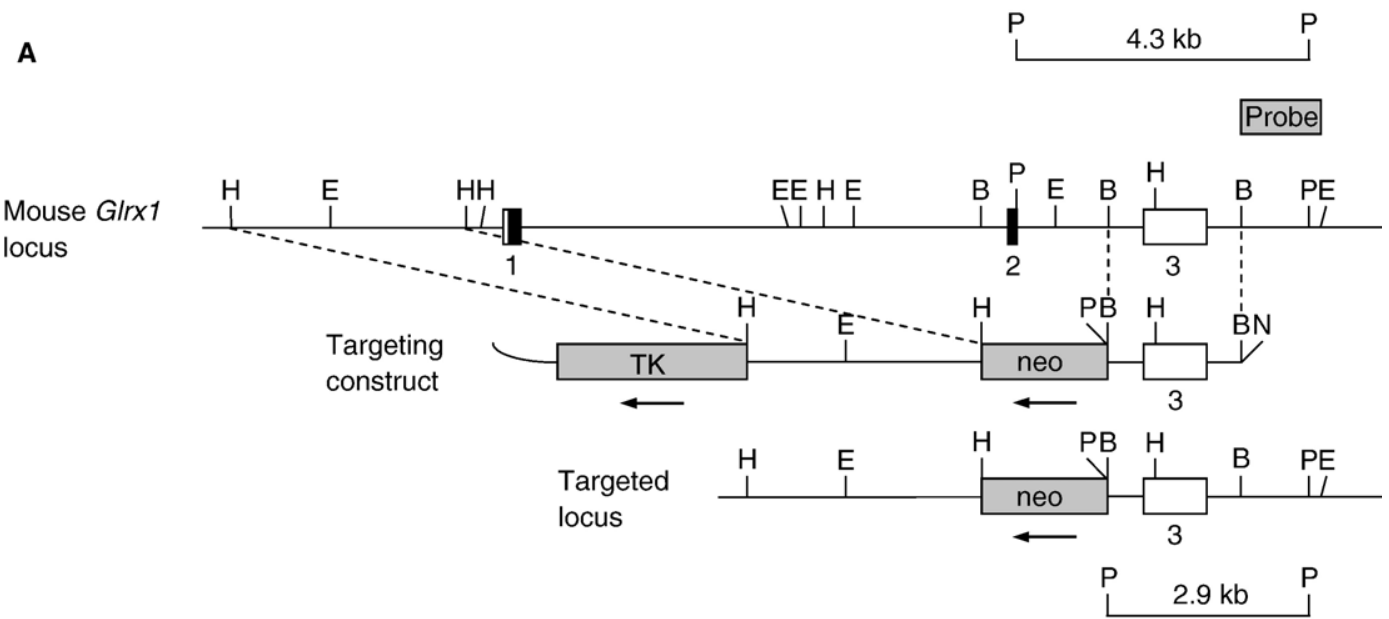

$1 \mathrm{~kb}$

B

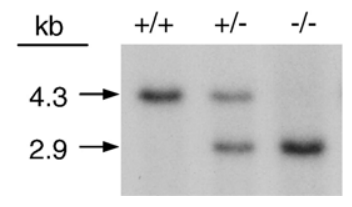

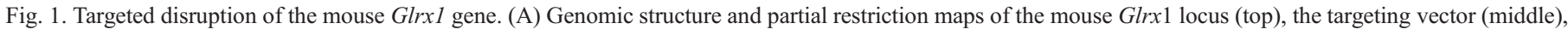

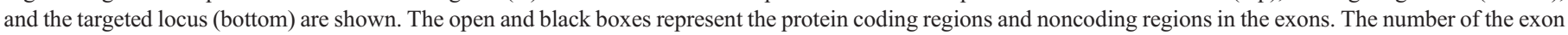

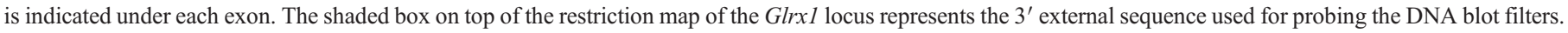

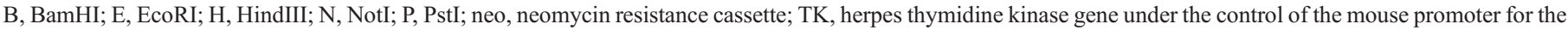

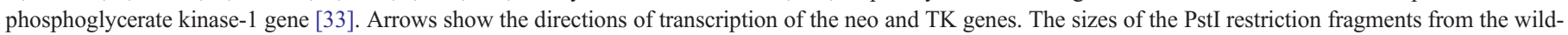

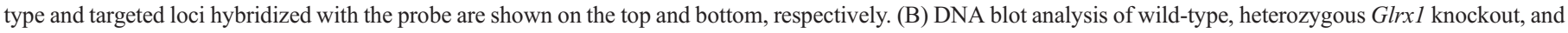

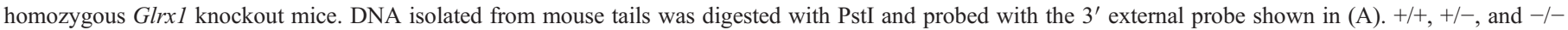

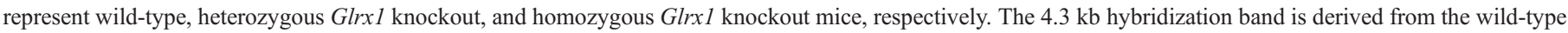
allele, and the $2.9 \mathrm{~kb}$ hybridization band from the mutated allele.

pPNT-5'Glrx1(-X). The resulting targeting vector, in which exons 1 and 2 were replaced by a neomycin resistance cassette, was linearized with NotI digestion and then transfected into R1 embryonic stem (ES) cells [29]. Fourteen clones (2.8\%) were identified from a total of 503 clones screened to contain the targeted Grxl allele. Chimeric mice were then generated by microinjecting clones 118 and 256 into blastocysts isolated from strain C57BL/6 mice [30]. All chimeric mice transmitted the targeted Glrxl allele into offspring. Heterozygous knockout mice were interbred to generate homozygous knockout mice.

\section{Preparation of tissue samples for gene expression studies}

Tissues from wild-type $\left(G \operatorname{lr} x 1^{+/+}\right)$, heterozygous Glrx 1 knockout $\left(G \operatorname{lr} x 1^{+--}\right)$, and homozygous Glrxl knockout $\left(G \operatorname{lr} x 1^{-1-}\right)$ mice were homogenized in guanidinium isothiocyanate solution, and total RNA was isolated according to the method described Chirgwin et al. [31]. Thirty micrograms of total RNA was denatured with glyoxyal and subjected to blot analysis according to the procedures described by Thomas [32]. For protein analysis, the tissues were homogenized in 1.5 to $2 \mathrm{ml}$ of lysis buffer $(50 \mathrm{mM}$ potassium phosphate buffer, $\mathrm{pH} 7.8$, $0.5 \%$ Triton X-100, and 3\% glycerol) containing protease inhibitor cocktail (P-8340; Sigma, St. Louis, MO, USA) and
$1 \mathrm{mM}$ phenylmethylsulfonyl fluoride with a Polytron homogenizer, followed by sonication. The homogenates were clarified by centrifugation at $20,000 \mathrm{~g}$ for $15 \mathrm{~min}$ and stored at $-70^{\circ} \mathrm{C}$. Protein concentrations of tissue homogenates were determined by the use of a bicinchoninic acid (BCA) protein assay kit (Pierce, Rockford, IL, USA). Thirty micrograms of tissue protein were separated on a SDS-polyacrylamide gel for protein blot analysis. The protein blot membrane was reacted with polyclonal antibodies against the human Grx1 protein generated in rabbits (kindly provided by Dr. Marjorie Lou of the University of Nebraska at Lincoln, Lincoln, NE, USA) and then with polyclonal antibodies against copper-zinc superoxide dismutase (Santa Cruz Biotechnology, Santa Cruz, CA, USA).

To understand the effect of Grx 1 deficiency on expression of different antioxidant enzymes, heart and lung homogenates prepared from six Glrx $1^{+/+}$mice and six Glrx $1^{-/-}$mice were subjected to protein blot analysis using antibodies against copper-zinc and manganese superoxide dismutases (Santa Cruz Biotechnology). In addition, the activity of catalase was measured by monitoring the decrease in absorbance of hydrogen peroxide at $240 \mathrm{~nm}$ [33]. Hydrogen peroxide was also used as a substrate for determining the activity of glutathione peroxidase in a reaction coupled to NADPH oxidation in the presence of sodium azide, which inhibits the activity of catalase [34]. 


\section{Preparation of tissue samples and assay for activity of Grx}

Frozen tissue samples were thawed on ice and $100 \mathrm{mg}$ of each was weighed and transferred to individual $15-\mathrm{ml}$ conical tubes prechilled on ice. Then $1.5 \mathrm{ml}$ of complete homogenization buffer [0.1 M K-monobasic/Na-dibasic, pH 7.5, supplemented with protease inhibitors aprotinin and leupeptin $(20 \mathrm{ng} / \mathrm{ml})]$ was added to each tube and homogenized twice for $30 \mathrm{~s}$ on ice using a Polytron homogenizer. The homogenates obtained were transferred to 2-ml centrifuge tubes and centrifuged at $100 \mathrm{~g}$ for $10 \mathrm{~min}$ at $4^{\circ} \mathrm{C}$ (to remove the cell debris). The supernatant (free of cell debris) was transferred into fresh $1.5-\mathrm{ml}$ tubes and centrifuged at $10,000 \mathrm{~g}$ for $30 \mathrm{~min}$ at $4{ }^{\circ} \mathrm{C}$. The resulting supernatant was used for assays of protein content and Grx activity.

Bovine serum albumin- $\left[{ }^{35} \mathrm{~S}\right] \mathrm{SSG}$ mixed disulfide $\left(\left[{ }^{35} \mathrm{~S}\right]\right.$ BSA-SSG) was used as substrate in a radiolabel assay for determining glutaredoxin activity. $\left[{ }^{35} \mathrm{~S}\right] \mathrm{BSA}-\mathrm{SSG}$ was prepared as described previously with the following modifications [35]. $S$-carboxymethyl BSA was initially reacted with $N$-succinimidylpyridyl bis (3,3'-dithiopropionate) and the reaction was then quenched with glycine. The modified BSA was subsequently separated from small molecules by dialysis against $100 \mathrm{mM}$ sodium phosphate, $\mathrm{pH} 7.0$, overnight with two changes of buffer, followed by reaction with $4 \mathrm{mM}\left[{ }^{35} \mathrm{~S}\right] \mathrm{GSH}$ for $1 \mathrm{~h}$ at room temperature. The resulting $\left[{ }^{35} \mathrm{~S}\right] \mathrm{BSA}-\mathrm{SSG}$ product was separated from $\left[{ }^{35} \mathrm{~S}\right] \mathrm{GSH}$ by G-25 chromatography, and it typically had $\geq 0.9 \mathrm{GS}$ eq $/ \mathrm{mol}$ of BSA.

The activity of Grx's in mouse tissues was measured by monitoring the time-dependent release of radioactivity from $\left[{ }^{35} \mathrm{~S}\right] \mathrm{BSA}-\mathrm{SSG}$. This assay of GSH-dependent deglutathionylation of protein-SSG is highly selective for Grx [17]. Also, the radiolabel assay avoids the multiple flaws associated with the GSSG reductase-coupled spectrophotometric analysis of tissue homogenates, including interference by light scattering and nonspecific NADPH oxidase activity. Aliquots of homogenates and assay buffer $(0.1 \mathrm{M} \mathrm{Na} / \mathrm{K}$ phosphate buffer, $\mathrm{pH} 7.4$, containing $0.5 \mathrm{mM}$ GSH and $0.2 \mathrm{mM} \mathrm{NADPH}$ ) were prewarmed to $30^{\circ} \mathrm{C}$ and mixed, and then an aliquot of $\left[{ }^{35} \mathrm{~S}\right] \mathrm{BSA}-\mathrm{SSG}$ (final concentration of $0.1 \mathrm{mM}$ ) was added to initiate the reaction (total volume $0.5 \mathrm{ml}$ ). Aliquots of the reaction mixtures were precipitated with ice-cold trichloroacetic acid (final concentration of $10 \%$ ) at $12 \mathrm{~s}$ and 1,2 , and $3 \mathrm{~min}$ of incubation. After centrifugation, the supernatants were analyzed for ${ }^{35} \mathrm{~S}$ by scintillation counting with $\geq 97 \%$ efficiency (cpm). The total rates of deglutathionylation (slopes of $\left[{ }^{35} \mathrm{~S}\right] \mathrm{GSH}$ eq released versus time) were corrected for nonenzymatic deglutathionylation by subtracting the rate of $\left[{ }^{35} \mathrm{~S}\right] \mathrm{GSH}$ eq released by GSH in the absence of tissue homogenates. Enzymatic rates are expressed as nmol of product/min/mg of protein.

\section{Mouse model of regional ischemia/reperfusion-induced heart injury}

Five Glrx $1^{+/+}$and six Glrx $1^{-/-}$mice at 10 to 12 weeks of age were anesthetized with tribromoethanol (275 mg/kg, ip). An endotracheal tube (PE 90) was inserted into the trachea approximately 5 to $8 \mathrm{~mm}$ past the larynx, and the mice were ventilated with room air (a tidal volume of $0.5 \mathrm{ml}$ ) using a rodent respirator (Columbus Instruments International, Columbus, $\mathrm{OH}$, USA) set at a respiratory rate of $110-120$ breaths $/ \mathrm{min}$. The heart was exposed through a left thoracotomy incision and the left anterior descending coronary artery (LAD) was ligated as described previously [36]. The chest was then closed after LAD ligation. After $60 \mathrm{mn}$ of LAD ligation, the ligature was released to allow reperfusion for $4 \mathrm{~h}$. The mouse was again anesthetized with tribromoethanol. At the dose of tribromoethanol used, there was no loss of animals due to repeated anesthesia. The heart was then perfused as a Langendorff preparation for $5 \mathrm{~min}$. The left coronary artery was reoccluded, and 1\% Evans blue was infused into the aorta and coronary arteries to determine the area at risk. The heart was then cut transversely into five sections, with one section made at the site of the ligature, and stained with triphenyltetrazolium chloride (TTC) for measurement of the infarct size as described previously [36]. The area at risk (unstained by Evans blue) was expressed as a percentage of the left ventricle (LV). The infarct size (area unstained by TTC) was expressed both as a percentage of the area at risk and as a percentage of LV [39]. The animal protocol was approved by the Animal Care Committee of East Tennessee State University.

\section{Assessment of hyperoxia-induced lung injury in mice}

The Glrx $1^{+/+}$and Glrx $1^{-/-}$mice at 10 weeks of age were used in exposure to $>99 \%$ oxygen in polystyrene chambers. The $\mathrm{CO}_{2}$ concentration was maintained at less than $5 \%$ by providing approximately 12 complete gas exchanges per hour. During the exposure, food and water ad libitum were provided, and the mice were kept under a $12 \mathrm{~h}$ on, $12 \mathrm{~h}$ off light cycle at all times. The mice were sacrificed at $72 \mathrm{~h}$ of exposure by overdose of pentobarbital and the lungs isolated. The left lobe was gently blotted dry with a piece of paper towel and the total weight (wet weight) measured. The lungs were then dried at $80^{\circ} \mathrm{C}$ under vacuum overnight and weigh again to measure the dry weight.

The extent of lung injury was also assessed by measuring the increases in protein content and number of neutrophils in bronchoalveolar lavage fluid (BALF). To do so, a second group of Glrx $1^{+/+}$and Glrx $1^{-/-}$mice was exposed to air or $>99 \%$ oxygen for $72 \mathrm{~h}$. Mice were then anesthetized with pentobarbital and the trachea was exposed. A Microfil needle (World Precision Instrument, Sarasota, FL, USA) was then inserted into the trachea through a small incision and fastened with a silk ligature around the trachea. Bronchoalveolar lavage was performed with $1 \mathrm{ml}$ phosphate-buffered saline (PBS) containing $3 \mathrm{mM}$ EDTA using a 1-ml syringe and repeated five times. The collected bronchoalveolar lavage fluid (BALF) (a total of $5 \mathrm{ml}$ ) was centrifuged at $1800 \mathrm{~g}$ to pellet the cells. The protein content in the supernatant was determined using a BCA assay kit. The pelleted cells were washed once and resuspended in $0.3 \mathrm{ml}$ of PBS containing EDTA, followed by dilution of $100 \mu 1$ of the cell suspension to 10 -fold with the same buffer. Two hundred microliters of the diluted cell suspension was cytocentrifuged and stained with the Hema 3 System (Fisher Scientific, 
Pittsburgh, PA, USA). The total number of neutrophils in a total of 200 white blood cells was counted. To determine the total numbers of cells in BALF samples, $10 \mu \mathrm{l}$ of the cell suspension was added to $10 \mathrm{ml}$ of Isoton diluent, followed by addition of 2 drops of Zap-O-Globin II lytic reagent to lyse red blood cells. The remaining intact cells (mainly white blood cells) were then counted with the Z1 Coulter Counter (Beckman Coulter, Inc., Fullerton, CA, USA). This allowed the estimation of the absolute number of neutrophils in BALF.

\section{Preparation of mouse embryonic fibroblasts (MEFs)}

The homozygous Glrxl knockout mice in a 129SV and C57BL/6 hybrid background and genetically matched wild-type mice were used for preparation of MEFs. Briefly, mouse embryos were dissected out from the pregnant dams 12.5 to 14.5 days postcoitus and internal organs removed. The embryos were then chopped into small pieces and stirred in $50 \mathrm{ml}$ of Hanks' balanced salt solution (without calcium and magnesium) containing $0.05 \%$ trypsin and $0.53 \mathrm{mM}$ EDTA (25300-054; Invitrogen, Carlsbad, CA, USA) in an Erlenmeyer flask at $37^{\circ} \mathrm{C}$ for $1 \mathrm{~h}$. Ten illigrams of DNase was added at the end of the incubation to decrease the viscosity of the cell suspension due to lysis of cells. The cell suspension was then passed through two layers of cheese cloth to remove the undigested and large chunks of tissues. The cells were then collected by centrifugation and cultured in Dulbecco's modified Eagle medium (Cat. No. 11995-065; Invitrogen) containing 10\% fetal bovine serum, penicillin, and streptomycin. MEFs from passages 2 to 4 were used for the study.

\section{Determination of cytotoxicity in MEFs by}

3-(4,5-dimethylthiazol-2-yl)-2,5-diphenyl-tetrazolium bromide (MTT) reduction and trypan blue assay

Twenty-four-well culture plates, each well seeded with $2 \times 10^{5}$ MEFs prepared from either Glrx $1^{+/+}$or $G$ lrx $1^{-/-}$mice, were used for cytotoxicity studies. For studying $\mathrm{H}_{2} \mathrm{O}_{2}$-induced cell death, the overnight cultures of MEFs were washed once with Dulbecco's phosphate-buffered saline (D-PBS; Base Cat. No. 14040; Invitrogen) supplemented with glucose (1 g/liter) and then treated with the same solution containing various concentrations of $\mathrm{H}_{2} \mathrm{O}_{2}(1 \mathrm{ml} /$ well $)$ at $37^{\circ} \mathrm{C}$ with $5 \% \mathrm{CO}_{2}$ for $1 \mathrm{~h}$. The D-PBS was removed at the end of treatment and cells were further incubated in $1 \mathrm{ml}$ of culture medium containing $0.5 \mathrm{mg}$ MTT for $3 \mathrm{~h}$. The MTT medium was subsequently removed and replaced with $0.5 \mathrm{ml}$ of isopropyl alcohol containing $0.01 \mathrm{~N} \mathrm{HCl}$ to dissolve the formazan crystals that were formed from reduction of MTT in the cells [37]. Then $0.2 \mathrm{ml}$ of the dissolved formazan was transferred into a 96-well plate and the absorbance at $570 \mathrm{~nm}$ measured using the SPECTRAmax Microplate Spectrophotometer (Molecular Devices, Sunnyvale, CA, USA). The net absorbance from the wells of MEFs treated with D-PBS without $\mathrm{H}_{2} \mathrm{O}_{2}$ was taken as $100 \%$ of MTT reduction. Cell viability was calculated by dividing the absorbance of $\mathrm{H}_{2} \mathrm{O}_{2}$ treated MEFs by that of the same MEFs treated with D-PBS without $\mathrm{H}_{2} \mathrm{O}_{2}$.
The same procedures were also used for quantifying cell viability after treatment with diamide [azodicarboxylic acid bis (dimethylamide)], diquat $\left(1,1^{\prime}\right.$-ethylene-2,2'-bipyridyldiylium dibromide), paraquat $\left(1,1^{\prime}\right.$-dimethyl-4, $4^{\prime}$-bipyridinium dichloride), and tumor necrosis factor $\alpha(\mathrm{TNF} \alpha)$ plus actinomycin $\mathrm{D}$, except the cells were treated in culture medium instead of D-PBS, and the treatment lasted $24 \mathrm{~h}$.

The extent of cell death was also assessed by a trypan blue exclusion assay. Briefly, MEFs were washed with D-PBS and trypsinized at the end of treatment. Fetal bovine serum was then added to the cell suspension to a final concentration of $10 \%$ to stop the trypsinization, followed by staining with $0.2 \%$ trypan blue for $5 \mathrm{~min}$. The numbers of dead, dark-blue-stained cells and live, unstained cells were counted using a hemocytometer.

\section{Detection of protein S-glutathionylation in MEFs by protein blot analysis}

For determining the effect of Grx1 deficiency on protein S-glutathionylation, 35-mm culture dishes, each seeded with $5 \times 10^{5} \mathrm{Glrx}^{+/+}$or Glrx $1^{-/-}$MEFs, were treated with $2.5 \mathrm{ml}$ of D-PBS containing glucose ( $1 \mathrm{~g} /$ liter $)$ and various concentrations of $\mathrm{H}_{2} \mathrm{O}_{2}$ for $1 \mathrm{~h}$ as described above. At the end of treatment, the attached cells were scraped into the D-PBS in which they were treated (including the floating cells as a result of detachment of cell monolayers due to treatment) and then precipitated by centrifugation. The cell pellet was resuspended in $0.3 \mathrm{ml}$ of lysis buffer $(50 \mathrm{mM}$ potassium phosphate buffer, $\mathrm{pH} 7.8$, containing $0.5 \%$ Triton X-100, 3\% glycerol) containing protease inhibitor cocktail (P-8340; Sigma), $1 \mathrm{mM}$ phenylmethylsulfonyl fluoride, and $28.5 \mathrm{mM} \mathrm{N}$-ethylmaleimide to prevent S-glutathionylation of proteins during sample manipulation. The cells were then lysed by freezing and thawing once, followed by sonication. The cell lysate was clarified by centrifugation and protein concentration determined by the use of a BCA protein assay kit (Pierce). Total cellular proteins were then separated on a nonreducing SDSpolyacrylamide gel and transferred to a piece of nitrocellulose membrane. The protein blot membrane was reacted with a monoclonal antibody against GSH (ViroGen, Watertown, MA, USA), followed by the standard procedures of chemiluminescence to visualize the antibody-interactive proteins.

\section{Statistical analysis}

The data were first analyzed by one-way analysis of variance followed by Newman-Keuls multiple comparison. For myocardial ischemia/reperfusion study, the difference between two groups was established by Student's $t$ test. Differences with a $p$ value $<0.05$ were considered statistically significant.

\section{Results}

Generation and characterization of knockout mice deficient in Grx1

We have previously generated a line of Glrx 1 knockout mice in which exon 2 and parts of introns 1 and 2 of the mouse Glrx 1 
gene were replaced by a neomycin resistance cassette. Unexpectedly, a species of Glrxl mRNA smaller than the wildtype Glrx I mRNA, presumably resulting from a fusion of exons 1 and 3 of the gene, is expressed in all tissues of homozygous knockout mice examined (Ho et al., unpublished data). We therefore repeated gene targeting of ES cells using a new construct in which both exons 1 and 2 of the mouse Glrxl gene were deleted (Fig. 1A). Chimeric mice generated from the targeted ES cells successfully transmitted the mutated Glrxl allele to their offspring and homozygous knockout mice were generated by interbreeding two heterozygous knockout mice (Fig. 1B).

An expression study was then performed to demonstrate that deletion of exons 1 and 2 inactivates the mouse Glrx 1 gene. As shown in Fig. 2A, an approximately 50\% decrease in Glrx 1 mRNA was found in tissues of $G l r x I^{+/-}$mice in comparison to Glrx $I^{+/+}$mice, and no Glrx 1 mRNA could be detected in tissues of lrx $]^{-/-}$mice. To determine whether expression of the Glrx2 gene is altered in tissues of Glrxl knockout mice, the same RNA blot membrane was rehybridized with a mouse cDNA coding for Grx2. When standardized against the mRNA level of glyceraldehyde-3-phosphate dehydrogenase (Gapd), the levels of Glrx2 mRNA in brain, kidney, liver, and lungs of mice with three different Glrxl genotypes were equivalent (Fig. 2A). (Note that less RNA from brain and kidney of a $\mathrm{Glrx}^{-/-}$mouse was loaded on the gel compared to that from the corresponding tissues of $\mathrm{GlrxI}^{+/+}$and $G l r x I^{+/-}$mice, as revealed by the levels of Gapd mRNA.) However, the level of Glrx 2 mRNA in the heart of a $\mathrm{Glr}_{\mathrm{N}} \mathrm{I}^{-/-}$mouse is slightly decreased relative to those of $\mathrm{GlrxI}^{+/+}$and $\mathrm{GlrxI}^{+/-}$mice.

Abolishment of Grx1 expression in tissues of Glrx $1^{-/-}$ mice was also confirmed by protein blot analysis (Fig. 2B), in which cytosolic copper-zinc superoxide dismutase (CuZnSOD) was used as the loading control because its specific content was unchanged in tissues of the knockout mice (see below). In addition, the specific Grx activity in tissue homogenates of ${\mathrm{Glr} x \mathrm{I}^{-/-}}^{-}$mice was also determined. In all cases there was a lack of detectable deglutathionylase activity in homogenates of the five tissues from the homozygous knockout mice. These data also indicate that the contribution of mitochondrial and nuclear Grx2 to total Grx activity in these mouse tissues is negligible and that no compensatory deglutathionylase activity is developed in the knockout mice.

To determine whether a deficiency in Grx1 affects expression of other antioxidant enzymes in heart and lungs, the activities of catalase and glutathione peroxidase were determined by activity assays and the levels of copper-zinc and manganese superoxide dismutases measured by protein blot studies. No changes in the activities and protein levels of these enzymes could be found in these two organs of Grx1-deficient mice compared to those of wild-type mice (data not shown).

A
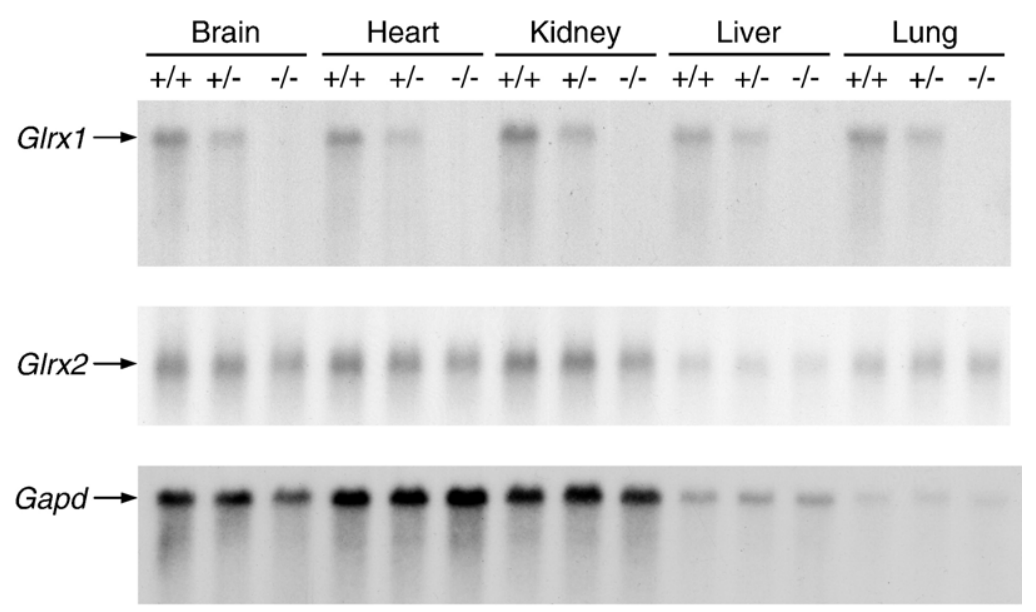

B

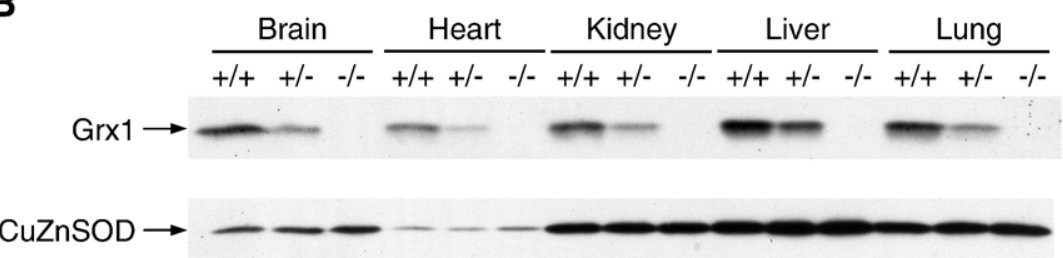

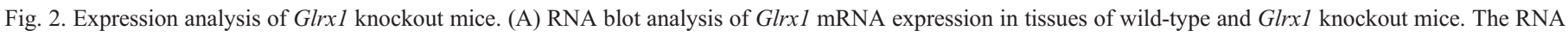

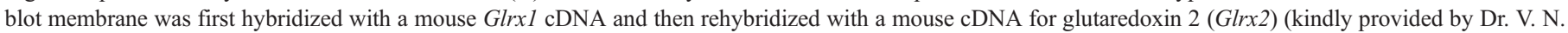

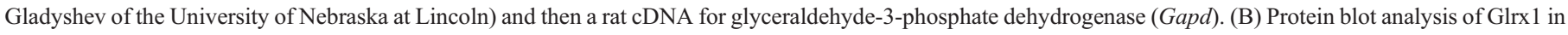

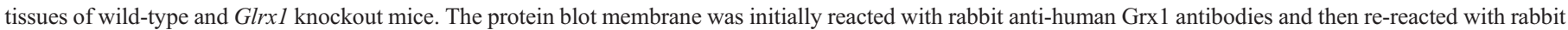

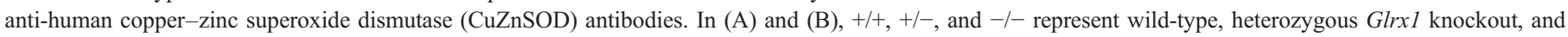
homozygous Glrxl knockout mice, respectively. 


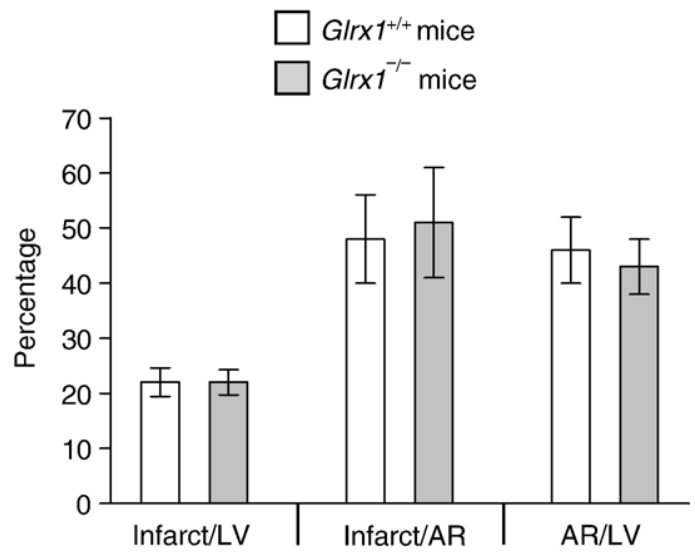

Fig. 3. Lack of effect of Grx1 deficiency on myocardial infarction in mice. Animals were subjected to 60 min of LAD coronary artery ligation followed by $4 \mathrm{~h}$ of reperfusion. The infarct size was standardized against LV and area at risk (AR). Each bar represents the mean $\pm \mathrm{SD}$.

The deficiency in Grx1 seems to have very limited effect on mouse development and physiology in general, because the homozygous knockout mice are healthy and fertile upon observation until 1 year of age.

Mice deficient in Grxl do not display greater myocardial injury after an ischemia/reperfusion insult

ROS have been postulated to participate in the pathogenesis of ischemia/reperfusion ( $\mathrm{I} / \mathrm{R}$ )-induced heart injury [1]. This hypothesis is supported by the findings that knockout mice deficient in CuZnSOD or cellular glutathione peroxidase are more sensitive to cardiac $\mathrm{I} / \mathrm{R}$ injury, and transgenic mice overexpressing either of these enzymes exhibit a resistant phenotype [38-42]. Analogously, overexpression of Grx1 in $\mathrm{H} 9 \mathrm{c} 2$ cardiomyocyte cells in vitro protects them from $\mathrm{H}_{2} \mathrm{O}_{2}$ induced apoptosis [24]; however, an in vivo effect of genetic manipulation of Grx1 has not been reported. The newly generated Glrxl knockout mice allowed us to investigate whether a deficiency in Grx1 renders mice more susceptible to regional I/R injury in vivo. Toward this end, GlrxI $I^{+/+}$and Glrx $1^{-/-}$mice were subjected to $60 \mathrm{~min}$ of LAD ligation, followed by $4 \mathrm{~h}$ of reperfusion. As shown in Fig. 3, the areas at risk, expressed as the percentage of the $\mathrm{LV}$, in hearts of Glrx $\mathrm{I}^{+/+}$ and Glrx $1^{-1-}$ mice were comparable $(46 \pm 6 \%$ vs. $43 \pm 5 \%$, respectively). The infarct sizes of hearts of llrxl $^{+/+}$and Glrx $1^{-/-}$mice, standardized against either LV or area at risk, were equivalent $(p>0.05)$. These results indicate that a deficiency in Grxl does not affect the infarct size in mouse hearts in an in vivo $\mathrm{I} / \mathrm{R}$ model.

\section{Deficiency in Grxl does not increase hyperoxia-induced lung injury in mice}

Exposure of animals to hyperoxia is known to cause an increased production of ROS in the lungs, leading to destruction of alveolar epithelium, inflammation, edema, and eventually death of animals [43]. Previous studies have shown that over- expression of manganese superoxide dismutase, extracellular superoxide dismutase (ECSOD), or 1-Cys peroxiredoxin (Prdx6) in the lungs of transgenic mice greatly attenuates lung damage resulting from exposure to hyperoxia [44-46]. Conversely, knockout mice deficient in ECSOD or Prdx6 are particularly vulnerable to the same model of lung injury $[47,48]$.

\section{A}

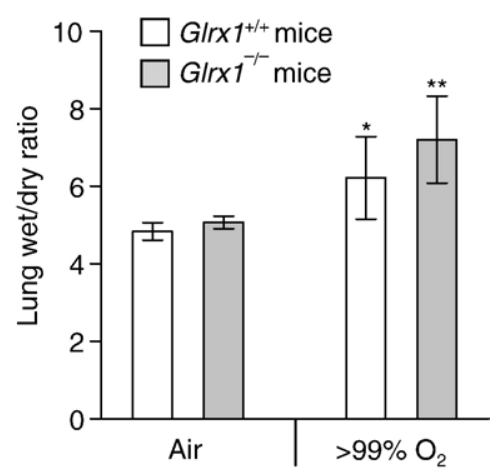

B
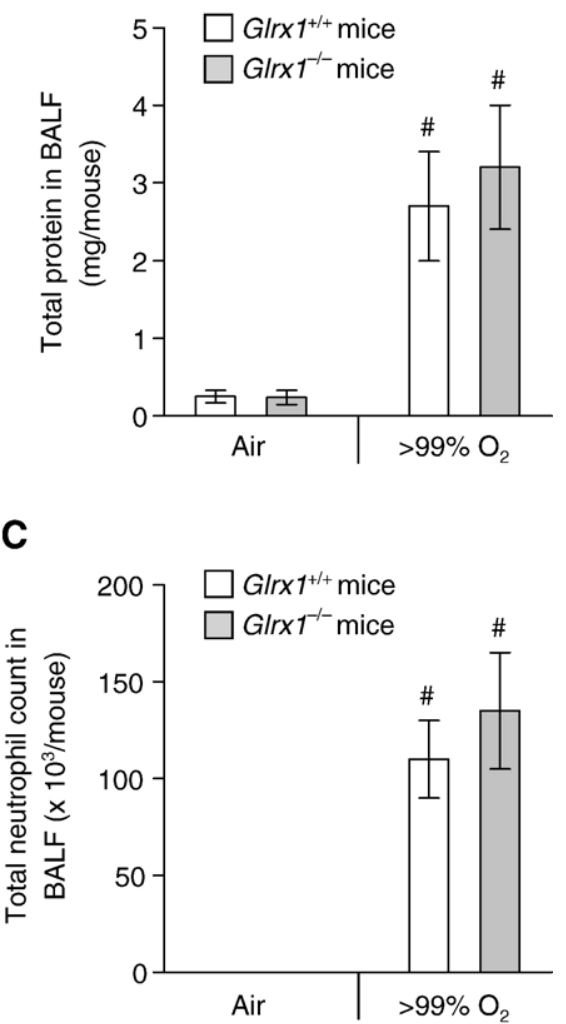

Fig. 4. Lung injury in Glrx $I^{+/+}$and Glrx $I^{-/-}$mice after exposure to $>99 \%$ oxygen for $72 \mathrm{~h}$. (A) The extents of lung edema (wet/dry ratio) are equivalent in both types of mice after exposure to hyperoxia. ${ }^{*} p<0.05$ vs. Glr $x I^{+/+}$mice exposed to air. ${ }^{* *} p<0.01$ vs. Glrx $I^{-/-}$mice exposed to air. In (B) and (C), hyperoxic exposure drastically increases the protein content and neutrophil count in BALF of both types of mice compared to those of the corresponding mice exposed to air. However, the extent of injury determined by these two parameters is not affected by the different Glrxl genotypes in the mice. \#p< 0.001 vs. mice with the same genotype exposed to air. In (C), the total numbers of neutrophils in the BALF of GlrxI $I^{+/+}$and $G l r x I^{-/-}$mice exposed to air were less than $10^{3}$ per mouse. In (A), (B), and (C), $N \geq 4$ for each group of mice and each bar represents the mean $\pm \mathrm{SD}$. 
These data have demonstrated the role of oxidative stress in hyperoxia-induced lung damage as well as the protective function of various antioxidant enzymes. However, the molecular and cellular mechanisms by which ROS cause lung injury are not understood. The available Glrxl knockout allowed us to investigate whether a decreased capacity in Grx1-mediated deglutathionylation of proteins would sensitize mice to hyperoxia-induced lung injury. As shown in Fig. 4A, exposure to $>99 \%$ oxygen caused lung edema in both $\mathrm{GlrxI}^{+/+}$and $\mathrm{Glrx}^{-/-}$mice as evident by the increased lung wet-to-dry ratios. Although the wet-to-dry ratio of Grx1deficient lungs $(7.2 \pm 1.1)$ is higher than that of wild-type lungs $(6.2 \pm 1.1)$, the difference is not statistically significant. The extent of lung injury was also assessed by measuring the changes in protein content and neutrophil count in BALF. As shown in Figs. $4 \mathrm{~B}$ and $4 \mathrm{C}$, exposure to hyperoxia drastically increases the protein content and neutrophil count in BALF of both types of mice compared to the corresponding mice exposed to air (Figs. 4B and 4C). However, these two parameters are not significantly different in lungs of Glrx $^{+/+}$ and $G l r x I^{-/-}$mice after exposure to hyperoxia. These data further support the conclusion derived from studies using lung wet-to-dry ratio that Grx 1 plays a very limited role in preventing hyperoxia-induced lung injury.

\section{Grxl-deficient MEFs are more susceptible to cell damage} induced by diquat and paraquat than by $\mathrm{H}_{2} \mathrm{O}_{2}$ and diamide

The function of Grx1 in cell defense against oxidative stress was also studied in fibroblasts prepared from embryos of Glrx $^{+/+}$and Glrx $1^{-/-}$mice. Fig. 5 shows the dose-dependent decrease in viability of MEFs as determined by the decline in the capability of the cells to reduce MTT after treatment with various oxidants. The time points of treatment were determined in separate experiments (data not shown) and were $1 \mathrm{~h}$ for treatment with $\mathrm{H}_{2} \mathrm{O}_{2}$ and $24 \mathrm{~h}$ for diamide, diquat, and paraquat. As shown in Fig. 5A, a deficiency in Grx1 does not render MEFs more susceptible to loss of cell viability due to toxicity of $\mathrm{H}_{2} \mathrm{O}_{2}$. Likewise, treatment of MEFs with diamide, a thiol-oxidizing agent, is not more potent in decreasing viability of Grx1deficient MEFs compared to its effect on wild-type MEFs (Fig. 5B). On the other hand, MEFs lacking Grx 1 are more vulnerable to cell damage induced by either diquat or paraquat, two chemicals that generate superoxide anion radical through the
A

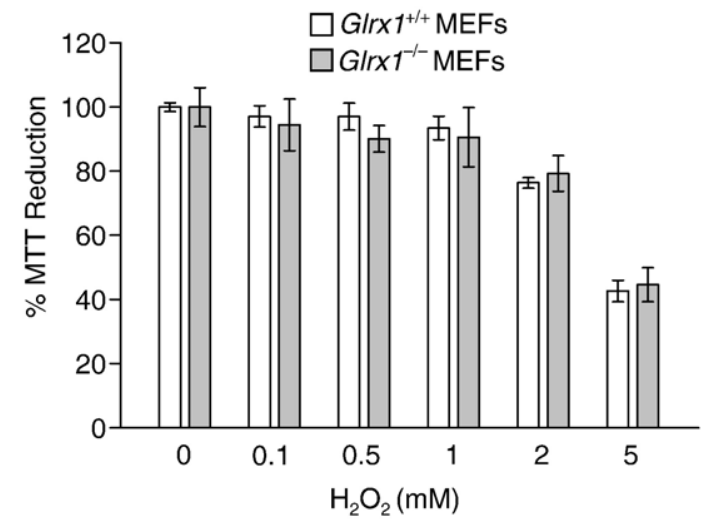

C

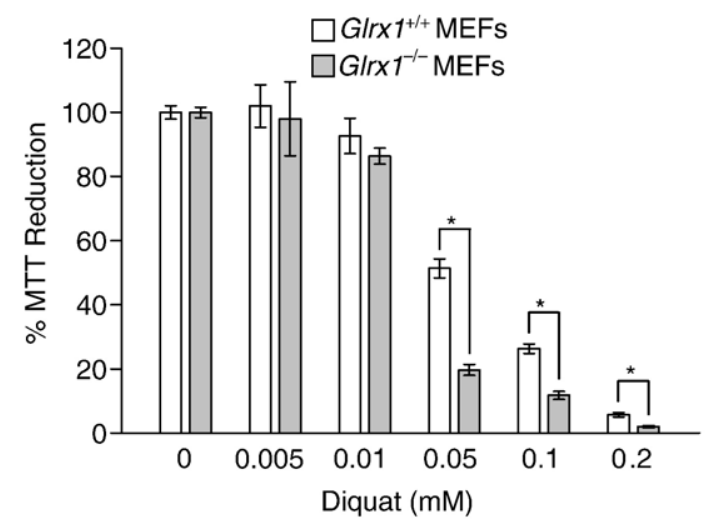

B

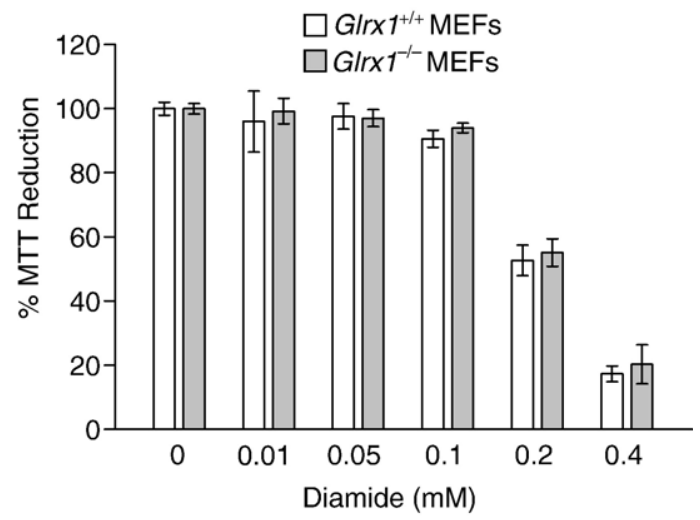

D

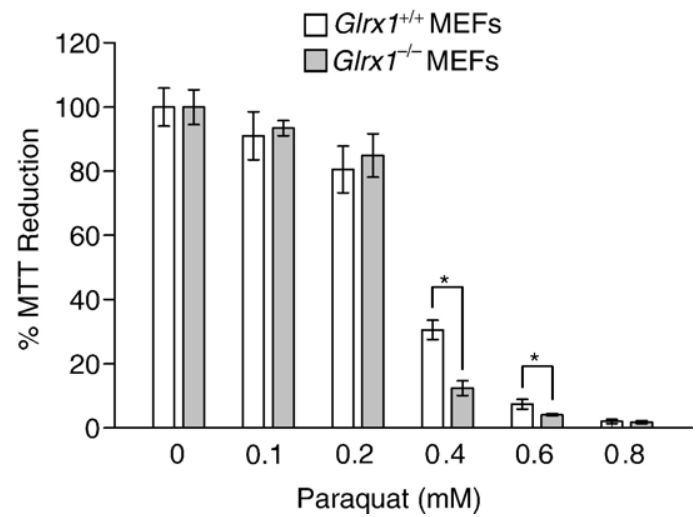

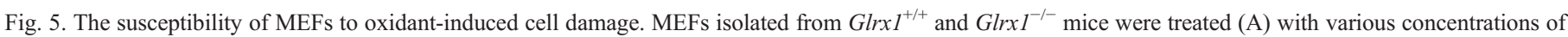

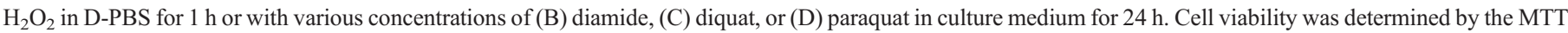

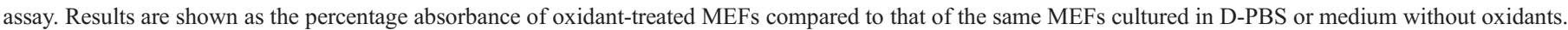

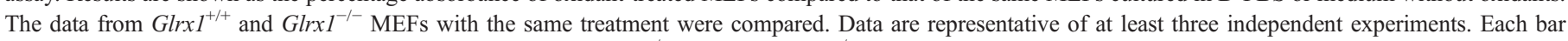
represents the mean $\pm \mathrm{SD}, n=4$ measurements. ${ }^{*} p<0.001$, Glrx $1^{+/+}$MEFs vs. Glrx $1^{-/-}$MEFs with the same treatment. 


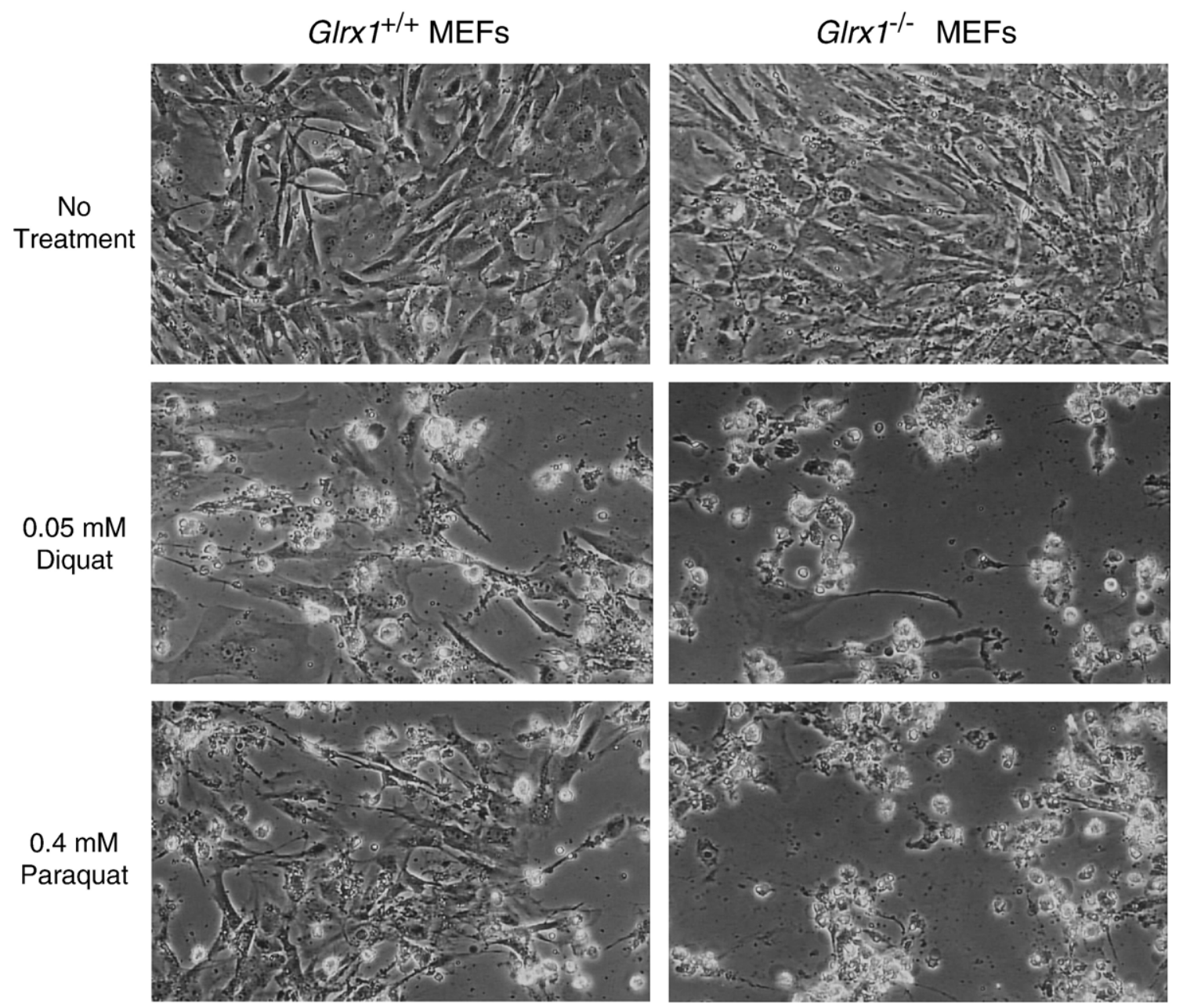

Fig. 6. Morphology of MEFs treated with diquat and paraquat. Glrx $I^{+/+}$and Glrx $I^{-/-}$MEFs were cultured in medium in the absence (as control) or presence of $0.05 \mathrm{mM}$ diquat or $0.4 \mathrm{mM}$ paraquat at $37^{\circ} \mathrm{C}$ for $24 \mathrm{~h}$. The genotypes of the MEFs and the treatments are shown on the top and the left, respectively. A more extensive detachment of cell monolayer and more cell death (shown as rounded cells) were seen in Glrx $1^{-/-}$MEFs treated with diquat or paraquat compared to Glrx $I^{+/+}$MEFs.

redox cycling mechanism (Figs. 5C and 5D). The increased susceptibility of Grx1-deficient MEFs to diquat and paraquat can also be concluded from the severity of morphological changes of the cells after treatment (Fig. 6).

The extent of cell death was also determined by a trypan blue exclusion assay in which trypan blue penetrates and stains only dead cells with permeable cell membranes. The results agree with those obtained from MTT studies as shown in Fig. 5 (data not shown).

Grx1-deficient MEFs are more resistant to apoptosis induced by tumor necrosis factor $\alpha$ plus actinomycin $D$

The involvement of ROS in cell apoptosis has been implicated in numerous studies [49]. We therefore determined whether a deficiency in Grx1 affects the execution of the cell apoptotic pathway. As shown in Fig. 7, apoptosis induced with tumor necrosis factor $\alpha$ plus actinomycin D causes a $36 \%$ decrease in viability of wild-type MEFs compared to controls, and the extent of cell death is attenuated in MEFs deficient in Grx1, suggesting a proapoptotic rather than an antiapoptotic role

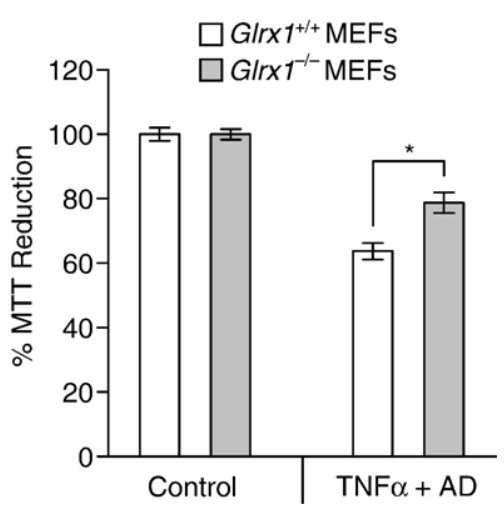

Fig. 7. Grx1-deficient MEFs are more tolerant to apoptosis induced by TNF $\alpha$ plus actinomycin D. Glrxl $I^{+/+}$and Glrx $1^{-/-}$MEFs were cultured in medium in the absence (as control) or presence of $10 \mathrm{ng} / \mathrm{ml} \mathrm{TNF} \alpha$ plus $50 \mathrm{ng} / \mathrm{ml}$ actinomycin $\mathrm{D}(\mathrm{AD})$ at $37^{\circ} \mathrm{C}$ for $24 \mathrm{~h}$. Cell viability was determined by the MTT assay as described for Fig. 5. Data are representative of two independent experiments. Each bar represents the mean $\pm \mathrm{SD}, n=4$ measurements. ${ }^{*} p<$ 0.001, Glrx $^{+/+}$MEFs vs. Glrx $1^{-/-}$MEFs. 
for Grx1 in this context. This result is analogous to findings reported recently in a study of hypoxia-induced apoptosis in pancreatic carcinoma cells [50].

Grx1 deficiency affects formation and reduction of protein-SSG mixed disulfides in MEFs in response to oxidative stress

Because Grx 1 catalyzes deglutathionylation of protein-SSG mixed disulfides, we sought to investigate whether a deficiency in Grx 1 affects the extent of S-glutathionylated proteins in MEFs in response to treatment with $\mathrm{H}_{2} \mathrm{O}_{2}$. As shown in Fig. 8A, two proteins that comigrate with the reduced proteins of 44 and $34 \mathrm{kDa}$ on the gel become more prominently S-glutathionylated in Grx1-deficient MEFs compared to wild-type MEFs after treatment with $\mathrm{H}_{2} \mathrm{O}_{2}$ at concentrations of $0.5,1$, and $2 \mathrm{mM}$. The levels of S-glutathionylation of other higher molecular weight proteins were markedly increased in both $G l r x I^{+/+}$and Glrx $1^{-/-}$ MEFs after being treated with $5 \mathrm{mM} \mathrm{H}_{2} \mathrm{O}_{2}$ for $1 \mathrm{~h}$, but the protein-SSG levels in the GlrxI $1^{-1-}$ cells were clearly higher than those in the GlrxI ${ }^{+/+}$cells. These observations indicate that cells deficient in Grx1 are more susceptible to $\mathrm{H}_{2} \mathrm{O}_{2}$-induced accumulation of S-glutathionylated proteins. We then examined the time course of deglutathionylation of the protein-SSG mixed disulfides that are formed due to $\mathrm{H}_{2} \mathrm{O}_{2}$ treatment. In this experiment, MEFs were treated with $5 \mathrm{mM} \mathrm{H}_{2} \mathrm{O}_{2}$ for $1 \mathrm{~h}$ and then cultured in regular medium in the absence of $\mathrm{H}_{2} \mathrm{O}_{2}$ for various periods of time before harvest for measurement of S-glutathionylated proteins. As shown in Fig. 8B, the glutathionyl moiety of most of the S-glutathionylated proteins, with the exception of a few high-molecular-weight proteins, is removed in wild-type MEFs within $1 \mathrm{~h}$ after termination of $\mathrm{H}_{2} \mathrm{O}_{2}$ treatment, consistent with rapid Grx1-catalyzed deglutathionylation, which occurs within minutes for most cellular proteins [22]. For Grx1deficient MEFs also, the majority of protein-SSG mixed disulfides were deglutathionylated at $1 \mathrm{~h}$, consistent with a typical nonenzymatic time course. There was a notable exception; namely deglutathionylation of an unidentified protein which comigrated with a reduced standard protein of $44 \mathrm{kDa}$ on the gel was particularly decreased in the absence of Grx 1 so that it remained extensively S-glutathionylated in $\mathrm{Glrx}^{-/-}$cells even at $3 \mathrm{~h}$ after removal of $\mathrm{H}_{2} \mathrm{O}_{2}$.
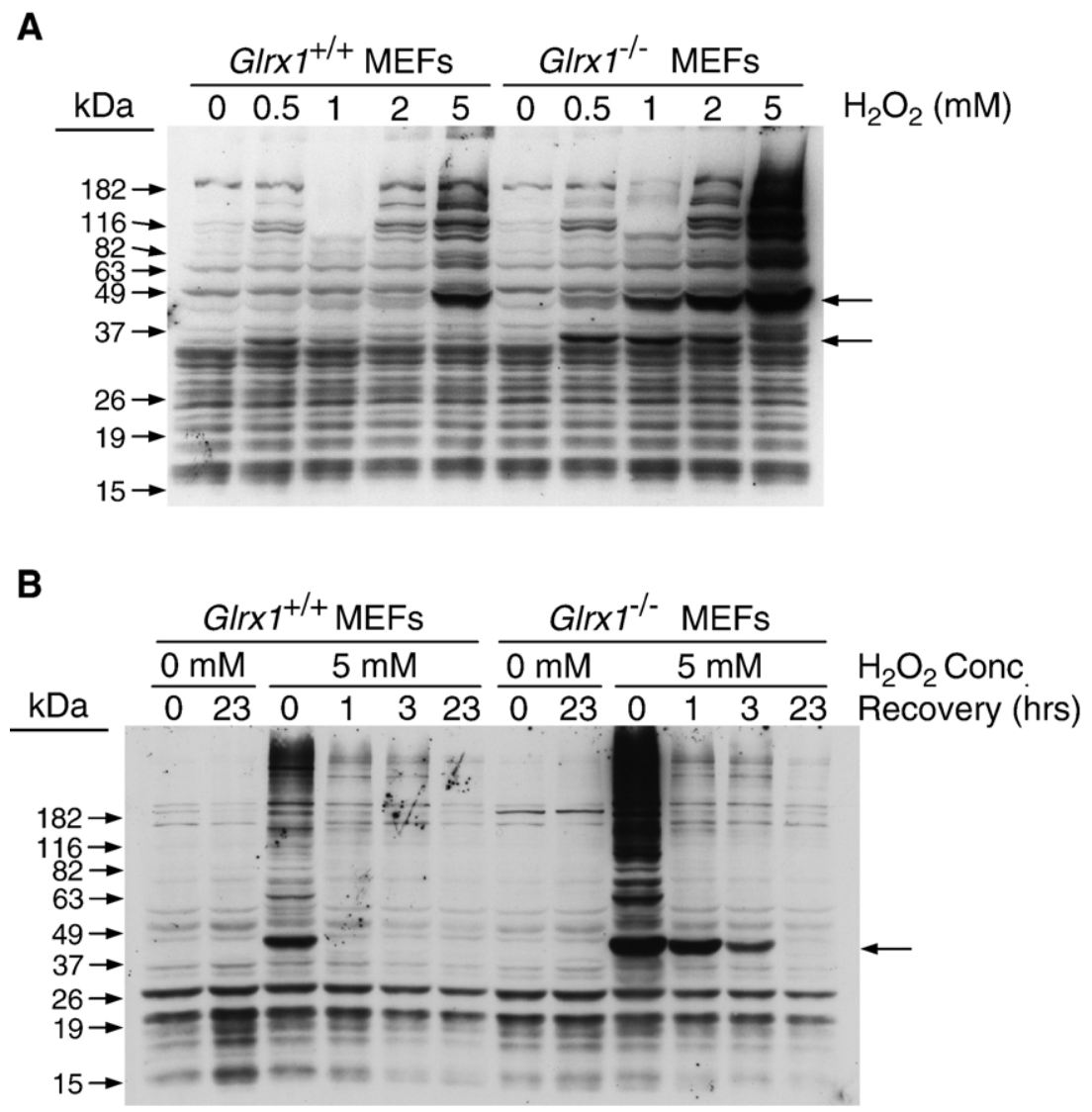

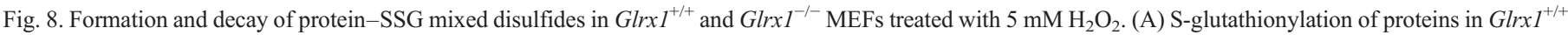

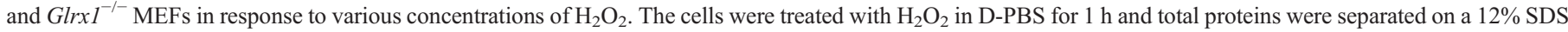

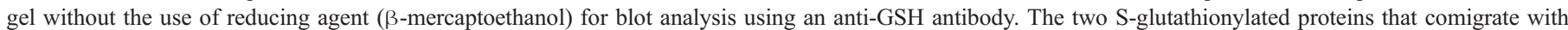

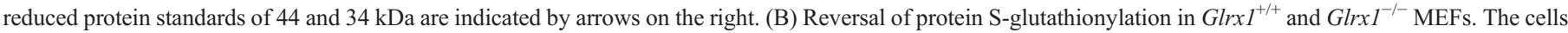

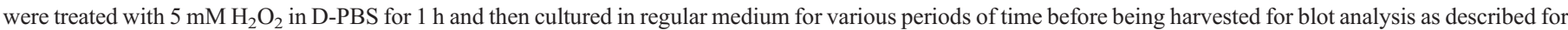

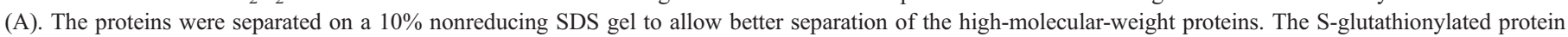
comigrating with a reduced protein of $44 \mathrm{kDa}$ is indicated by an arrow on the right. 


\section{Discussion}

In eukaryotes, a precise control of oxidation/reduction of protein thiols is essential for normal cell physiology. For example, formation of intra- and interprotein disulfides is required for maturation, secretion, and function of a large number of secretory proteins and is also critical for the function of some of the intracellular proteins. Oxidative protein folding in the endoplasmic reticulum (ER) of cells can be catalyzed by protein disulfide isomerase, which is maintained in its oxidized state by Ero1 (ER oxidoreductin 1), as well as by members belonging to the family of quiescin-sulfhydryl oxidase (QSOX) [51,52]. In addition, Erv1p, a member of the QSOX family that is located in the mitochondrial intermembrane space, is involved in mitochondrial biogenesis and assembly of cytosolic iron-sulfur cluster-containing proteins $[53,54]$, suggesting the role of disulfide bond formation in these critical cellular processes. These observations illustrate the importance of thiol oxidation in normal protein function and cell physiology. On the other hand, the cytosolic compartment of cells is highly reduced and therefore most of the cysteine residues of intracellular proteins are in the reduced state. For these proteins, thiol oxidation as a result of oxidative stress may represent an undesirable event. Fortunately, certain forms of oxidized protein thiols can be reduced by members of the thioredoxin fold family, Trx and Grx. This study set out to further our understanding of the in vivo functions of Grx1 using a line of knockout mice deficient in this enzyme. In contrast to mice deficient in $\operatorname{Trx} 1$ or Trx2, which die in utero [55,56], mice lacking Grx1 develop normally and are healthy upon observation to 1 year of age, indicating the distinct functions of Trx's and Grx1 in mouse development.

Due to the high intracellular concentration of GSH, Sglutathionylation of proteins occurs in cells under normal culturing conditions and is further enhanced in cells under oxidative stress (Fig. 7A). S-glutathionylation can inactivate the catalytic function of many proteins such as transcription factors NF- $\kappa$ B and NF-1 $[50,57,58]$, protein tyrosine phosphatase 1B (PTP-1B) $[59,60]$, and protein kinase $C-\alpha[61]$. However, the activities of a number of other proteins, such as HIV-1 protease, glutathione $S$-transferase, and Ras, are enhanced by Sglutathionylation [62-64]. In certain cases, the altered protein function due to S-glutathionylation has been shown to play a role in the regulation of cell physiology. For example, S-glutathionylation-mediated inactivation of PTP-1B in cells treated with epidermal growth factor may be critical for sustaining/enhancing the receptor tyrosine kinase-mediated signaling pathway [65]. On the other hand, activation of Ras due to S-glutathionylation in vascular smooth muscle cells in response to angiotensin II results in stimulation of protein synthesis, potentially leading to cell hypertrophy [64]. Therefore, S-glutathionylation of proteins may represent a novel mechanism by which redox modulates cell signaling and physiology [13]. However, extensive Sglutathionylation of proteins in cells after oxidative stress may represent the underlying mechanism for oxidant-induced tissue injury. In this report, we tested whether a deficiency in Grx1, and therefore a decreased capacity for deglutathionylation, would sensitize mice to injury in heart and lungs induced by ischemia/ reperfusion and hyperoxia, respectively, two models in which the role of ROS in causing tissue damage has been established. Our results show that mice lacking Grx 1 are not more vulnerable to these two models of oxidant-mediated tissue injury, suggesting that generalized S-glutathionylation of cytosolic proteins, which is reversible by Grx1, is not a major cause of tissue damage.

However, these studies do not exclude the physiological role of Grx 1 in other models of oxidant-mediated tissue response and injury. For example, Cys-179 of the inhibitory $\kappa \mathrm{B}$ kinase $\beta$ (IKK- $\beta$ ) subunit of inhibitory $\kappa \mathrm{B}(\mathrm{I} \kappa \mathrm{B})$ kinase is a target of oxidation, resulting in the formation of IKK- $\beta-$ SSG mixed disulfide [66]. This greatly abrogates the kinase activity of IKK- $\beta$, thereby decreasing the phosphorylation of I $\mathrm{KB}$ and the subsequent activation of the transcription factor NF-kB. The function of Grx1 in preventing oxidation-mediated inactivation of IKK- $\beta$ has been demonstrated by experiments using cultured cells in which expression of Grx 1 is either up- or down-regulated by gene transfection. This conclusion is further supported by the observations that primary tracheal epithelial cells isolated from

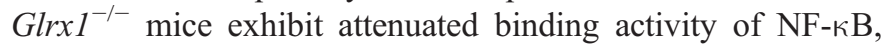
nuclear translocation of the RelA subunit of NF- $\kappa \mathrm{B}$, and activation of expression of chemokines in response to treatment with lipopolysaccharide compared to the same cells isolated from Glrx $1^{+/+}$mice [66].

A second example is illustrated by the results that MEFs deficient in Grx1 are more tolerant to apoptosis induced by TNFoplus AD (Fig. 7). The molecular mechanism underlying this observation was suggested by a recent report from Pan and Beck [67]. In their studies, down-regulation of Grx1 expression by interference RNA desensitizes human umbilical vein endothelial cells (HUVECs) to cell death induced by TNFoplus cycloheximide. This is because treatment of HUVECs with these agents enhances S-glutathionylation of procaspase-3, which inhibits its cleavage and activation during the apoptotic response. In this model of programmed cell death, Grx 1 actually functions in promoting apoptosis by deglutathionylating the procaspase-3-SSG mixed disulfide, thereby facilitating formation of the active caspase-3. Grx 1 can also enhance apoptosis through a different mechanism. As shown by Nieminen and colleagues, knock-down of Grx1 attenuates $N$-acetyl-Lcysteine-induced apoptosis of pancreatic carcinoma cells exposed to hypoxia [50]. In this case the action of Grx1 is attributed to its unusual ability to use the glutathionyl radical to promote S-glutathionylation of the p65 subunit of NF- $\kappa B$, thereby inhibiting the antiapoptotic action of NF- $\kappa$ B. These mechanistic insights indicate that the consequences of protein Sglutathionylation and therefore the role of Grx 1 in reversing or promoting this process may vary in different models of cell injury and response involving oxidative stress. Thus, this newly generated line of knockout mice should prove a valuable tool in addressing the functional role of Grx1 in a variety of disease models in which cellular redox is perturbed.

The effect of Grx 1 deficiency on the response of MEFs to oxidants was also studied. Lack of Grx1 did not exacerbate the toxic effects of $\mathrm{H}_{2} \mathrm{O}_{2}$ or, surprisingly, diamide, an agent that more selectively promotes protein-SSG formation, on the 
viability of cells. On the other hand, MEFs deficient in Grx1 were more susceptible to injury induced by diquat or paraquat, suggesting that different oxidants may damage the cells via distinct mechanisms, some of which may not be attenuated by Grx1-dependent deglutathionylation. Furthermore, in the model of $\mathrm{H}_{2} \mathrm{O}_{2}$-induced cell injury, the degree of protein S-glutathionylation seems not to correlate with the extent of cell death, as more extensive S-glutathionylation of proteins in Grx1-deficient MEFs is not associated with an increase in cell death (Figs. 5, 6, and 8). This is also true for MEFs treated with diquat and paraquat. Both agents cause more cell death in Grx1-deficient MEFs than in wild-type MEFs, yet no increases in protein Sglutathionylation can be found in either type of MEF at 12 or $24 \mathrm{~h}$ posttreatment (data not shown). Although some of these observations seem to contradict the hypothesis that oxidation of protein thiols, particularly formation of protein-SSG mixed disulfides, contributes to oxidant-induced cell damage, there are several mitigating considerations. First, the time frame of commitment to cell death is likely much shorter than the time for progression to cell death. Therefore it is important to examine early events associated with changes in S-glutathionylation status and relative rates of deglutathionylation. Second, examination of gross changes in protein-SSG status may not be reflective of specific molecular events associated with commitment to cell death. Because the sensitivity of the monoclonal antibody against GSH has not yet been characterized and the separation on an SDS gel is relatively limited, Sglutathionylation of certain proteins that play a critical role in the cellular injury response to oxidants may not be detected due to the limited sensitivity of the antibody, or they may be masked by the proteins with a high degree of S-glutathionylation (Fig. 8). Third, the use of cell death as an end point may not be appropriate for correlating the extent of cell injury to the level of protein S-glutathionylation. Nevertheless, overexpression of Grx1 has been shown to prevent cells from oxidant-mediated damage in response to dopamine, $\mathrm{H}_{2} \mathrm{O}_{2}$, and high concentrations of glucose [21-26]. These results support the hypothesis that oxidant-induced cell injury is partly mediated through Sglutathionylation of proteins. However, direct measures of protein-SSG status of specific proteins in these studies were not performed, so it remains to be determined whether an increased expression of Grx1 affects the levels of protein S-glutathionylation in each case.

Finally, MEFs deficient in Grx1 are more vulnerable than wild-type MEFs to S-glutathionylation of proteins induced by a high concentration of $\mathrm{H}_{2} \mathrm{O}_{2}$ (Fig. 8A), indicating that Grx1 is an important cellular mechanism of deglutathionylation, as also shown in several previous studies [16,17,64,66-68]. For example, overexpression of Grx1 in cells has been shown to cause deglutathionylation of several targeted proteins such as Ras, IKK- $\beta$, and procaspase-3 $[64,66,67]$, and down-regulation of Grx 1 by RNA interference retards deglutathionylation of S-glutathionylated IKK- $\beta$, procaspase-3, and actin [66-68]. The current and other earlier studies suggest that Grx1 may preferentially deglutathionylate certain cellular proteins. Further studies to identify the protein targets of Grx1-mediated deglutathionylation should advance our understanding in redox regulation of cellular function and oxidant-induced cell damage.

In summary, a line of knockout mice deficient in Grx1 was generated in this study for understanding the role of this protein in oxidant-mediated cell and tissue injury. Our studies showed that a deficiency in Grx1 does not affect the susceptibility of mice to acute injury of heart and lungs induced by ischemia/ reperfusion and hyperoxia, respectively. This observation may preclude a role for Grx1 in protection of the heart and lung cells. However, at present we cannot exclude the possibility that alternative or compensatory regulatory mechanisms may have developed in these mice, which are deprived of Grx 1 at the embryonic stage. On the other hand, we observed that Grx1 deficiency selectively sensitizes MEFs to oxidant-induced cell death and that Grx1 may exert its function on specific protein targets. These results indicate the complexity of the mechanisms by which each oxidant causes cell injury. Identification of the cellular protein targets of S-glutathionylation that are formed due to alteration of cellular redox status and after oxidative stress using this line of knockout mice should provide new insights into our understanding of cell and tissue physiology in both health and disease.

\section{Acknowledgments}

We thank Dr. Richard Mulligan of Harvard University and Dr. Andras Nagy of Mount Sinai Hospital in Toronto for the gifts of plasmid pPNT and R1 embryonic stem cells, respectively; Syntex, Inc. (Palo Alto, CA, USA) for the gift of ganciclovir; Mr. Xiufeng Gao and Dr. David Bassett of Wayne State University for assistance in studies of the bronchoalveolar lavage fluid; and Ms. Ping T. Ho for sequencing the entire mouse Glrxl gene. The work was supported by NIH Grant HL63317 and American Heart Association Greater Midwest Affiliate Grant 0455876Z to Y.-S.H.; by NIH Grant HL87271, a grant from the Department of Veterans Affairs Merit Review, and a grant-in-aid from the American Heart Association Southeast Affiliate to B.H.L.C.; and by NIH Grants AG024413 and AG15885 and a Merit Review grant from the Department of Veterans Affairs to J.J.M. The use of equipment in the Imaging and Cytometry Facility Core and Cell Culture Facility Core was supported by Center Grant P30 ES06639.

\section{References}

[1] Cross, C. E.; Halliwell, B.; Borish, E. T.; Pryor, W. A.; Ames, B. N.; Saul, R. L.; McCord, J. M.; Harman, D. Oxygen radicals and human disease. Ann. Intern. Med. 107:526-545; 1987.

[2] Stadtman, E. R. Oxidation of free amino acids and amino acid residues in proteins by radiolysis and by metal-catalyzed reactions. Annu. Rev. Biochem. 62:797-821; 1993.

[3] Biteau, B.; Labarre, J.; Toledano, M. B. ATP-dependent reduction of cysteine-sulphinic acid by $S$. cerevisiae sulphiredoxin. Nature 425: 980-984; 2003.

[4] Budanov, A. V.; Sablina, A. A.; Feinstein, E.; Koonin, E. V.; Chumakov, P. M. Regeneration of peroxiredoxins by p53-regulated sestrins, homologs of bacterial AhpD. Science 304:596-600; 2004.

[5] Chang, T. S.; Jeong, W.; Woo, H. A.; Lee, S. M.; Park, S.; Rhee, S. G. Characterization of mammalian sulfiredoxin and its reactivation of 
hyperoxidized peroxiredoxin through reduction of cysteine sulfinic acid in the active site to cysteine. J. Biol. Chem. 279:50994-51001; 2004.

[6] Woo, H. A.; Jeong, W.; Chang, T. S.; Park, K. J.; Park, S. J.; Yang, J. S.; Rhee, S. G. Reduction of cysteine sulfinic acid by sulfiredoxin is specific to 2-cys peroxiredoxins. J. Biol. Chem. 280:3125-3128; 2005.

[7] Holmgren, A. Thioredoxin and glutaredoxin systems. J. Biol. Chem. 264:13963-13966; 1989.

[8] Yoshitake, S.; Nanri, H.; Fernando, M. R.; Minakami, S. Possible differences in the regenerative roles played by thioltransferase and thioredoxin for oxidatively damaged proteins. J. Biochem. 116:42-46; 1994.

[9] Gravina, S. A.; Mieyal, J. J. Thioltransferase is a specific glutathionyl mixed disulfide oxidoreductase. Biochemistry 32:3368-3376; 1993.

[10] Wollman, E. E.; d'Auriol, L.; Rimsky, L.; Shaw, A.; Jacquot, J.-P.; Wingfield, P.; Graber, P.; Dessarps, F.; Robin, P.; Galibert, F.; Bertoglio, J.; Fradelizi, D. Cloning and expression of a cDNA for human thioredoxin. J. Biol. Chem. 263:15506-15512; 1998.

[11] Spyrou, G.; Enmark, E.; Miranda-Vizuete, A.; Gustafsson, J. Cloning and expression of a novel mammalian thioredoxin. J. Biol. Chem. 272: 2936-2941; 1997

[12] Lillig, C. H.; Holmgren, A. Thioredoxin and related molecules-from biology to health and disease. Antioxid. Redox Signaling 9:25-57; 2007.

[13] Shelton, M. D.; Chock, P. B.; Mieyal, J. J. Glutaredoxin: role in reversible protein S-glutathionylation and regulation of redox signal transduction and protein translocation. Antioxid. Redox Signaling 7:348-366; 2005.

[14] Meister, A.; Anderson, M. E. Glutathione. Аnnu. Rev. Biochem. 52: 711-760; 1983.

[15] Yang, Y.; Jao, S.; Nanduri, S.; Starke, D. W.; Mieyal, J. J.; Qin, J. Reactivity of the human thioltransferase (glutaredoxin) C7S, C25S, C78S, C82S mutant and NMR solution structure of its glutathionyl mixed disulfide intermediate reflect catalytic specificity. Biochemistry 37:17145-17156; 1998.

[16] Jung, C. H.; Thomas, J. A. S-glutathiolated hepatocyte proteins and insulin disulfides as substrates for reduction by glutaredoxin, thioredoxin, protein disulfide isomerase, and glutathione. Arch. Biochem. Biophys. 335:61-72; 1996.

[17] Chrestensen, C. A.; Starke, D. W.; Mieyal, J. J. Acute cadmium exposure inactivates thioltransferase (glutaredoxin), inhibits intracellular reduction of protein-glutathionyl-mixed disulfides, and initiates apoptosis. J. Biol. Chem. 275:26556-26565; 2000.

[18] Wells, W. W.; Yang, Y.; Deits, T. L.; Gan, Z. R. Thioltransferases. Adv. Enzymol. Relat. Areas Mol. Biol. 66:149-201; 1993.

[19] Lundberg, M.; Johansson, C.; Chandra, J.; Enoksson, M.; Jacobsson, G.; Ljung, J.; Johansson, M.; Holmgren, A. Cloning and expression of a novel human glutaredoxin (Grx2) mitochondrial and nuclear isoforms. J. Biol. Chem. 276:26269-26275; 2001.

[20] Gladyshev, V. N.; Liu, A.; Novoselov, S. V.; Krysan, K.; Sun, Q. A.; Kryukov, V. M.; Kryukov, G. V.; Lou, M. F. Identification of a new mammalian glutaredoxin (thiotransferase), grx2. J. Biol. Chem. 276: 30374-30380; 2001

[21] Meyer, E. B.; Wells, W. W. Thiotransferase increases resistance of MCF-7 cells to adriamycin. Free Radic. Biol. Med. 26:770-776; 1999.

[22] Daily, D.; Vlamis-Gardikas, A.; Offen, D.; Mittelman, L.; Melamed, E.; Holmgren, A.; Barzilai, A. Glutaredoxin protects cerebellar granule neurons from dopamine-induced apoptosis by activating NF- $\kappa B$ via Ref-1. J. Biol. Chem. 276:1335-1344; 2001.

[23] Daily, D.; Vlamis-Gardikas, A.; Offen, D.; Mittelman, L.; Melamed, E.; Holmgren, A.; Barzilai, A. Glutaredoxin protects cerebellar granule neurons from dopamine-induced apoptosis by dual activation of the Rasphosphoinositide 3-kinase and Jun N-terminal kinase pathways. J. Biol. Chem. 276:21618-21626; 2001.

[24] Murata, H.; Ihara, Y.; Nakamura, H.; Yodoi, J.; Sumikawa, K.; Kondo, T. Glutaredoxin exerts an antiapoptotic effect by regulating the redox state of Akt. J. Biol. Chem. 278:50226-50233; 2003.

[25] Song, J. J.; Rhee, J. G.; Suntharalingam, M.; Walsh, S. A.; Spitz, D. R.; Lee, Y. J. Role of glutaredoxin in metabolic oxidative stress: glutaredoxin as a sensor of oxidative stress mediated by $\mathrm{H}_{2} \mathrm{O}_{2}$. J. Biol. Chem. 277: 46566-46577; 2002
[26] Song, J. J.; Lee, Y. J. Differential role of glutaredoxin and thioredoxin in metabolic oxidative stress-induced activation of apoptosis signal-regulating kinase 1. Biochem. J. 373:845-853; 2003.

[27] Park, J. B.; Levine, M. The human glutaredoxin gene: determination of its organization, transcription start point, and promoter analysis. Gene 197:189-193; 1997.

[28] Tybulewicz, V. C. J.; Crawford, C. E.; Jackson, P. K.; Bronson, R. T.; Mulligan, R. C. Neonatal lethality and lymphopenia in mice with a homozygous disruption of the c-abl proto-oncogene. Cell 65:1153-1163; 1991.

[29] Nagy, A.; Rossant, J.; Nagy, R.; Abramow-Newerly, W.; Roder, J. C. Derivation of completely cell culture-derived mice from early-passage embryonic stem cells. Proc. Natl. Acad. Sci. USA 90:8424-8428; 1993.

[30] Bradley, A. Production and analysis of chimaeric mice. In: Roberston, E.J., ed. Tetratocarcinomas and embryonic stem cells: a practical approach. Oxford: IRL Press; 1987:113-151.

[31] Chirgwin, J. M.; Przybyla, A. E.; MacDonald, R. J.; Rutter, W. J. Isolation of biologically active ribonucleic acid from sources enriched in ribonuclease. Biochemistry 18:5294-5299; 1979.

[32] Thomas, P. S. Hybridization of denatured RNA and small DNA fragments transferred to nitrocellulose. Proc. Natl. Acad. Sci. USA 77:5201-5205; 1980.

[33] Aebi, H. E. Catalase in vitro. Methods Enzymol. 105:121-126; 1984.

[34] Little, C.; Olinescu, R.; Reid, K. G.; O’Brien, P. J. Properties and regulation of glutathione peroxidase. J. Biol. Chem. 245:3632-3636; 1970.

[35] Srinivasan, U.; Mieyal, P. A.; Mieyal, J. J. pH profiles indicative of ratelimiting nucleophilic displacement in thioltransferase catalysis. Biochemistry 36:3199-3206; 1997.

[36] Chen, Z.; Siu, B.; Ho, Y.-S.; Vincent, R.; Hamdy, R. C.; Chua, B. H. L. Overexpression of MnSOD protects against myocardial ischemia/reperfusion injury in transgenic mice. J. Mol. Cell. Cardiol. 30:2281-2289; 1998.

[37] Berridge, M. V.; Tan, A. S. Characterization of the cellular reduction of 3-(4,5-dimethylthiazol-2-yl)-2,5-diphenyltetrazolium bromide (MTT): subcellular localization, substrate dependence, and involvement of mitochondrial electron transport in MTT reduction. Arch. Biochem. Biophys. 303:474-482; 1993

[38] Yoshida, T.; Maulik, N.; Engelman, R. M.; Ho, Y.-S.; Das, D. K. Targeted disruption of the mouse Sod1 gene makes the heart vulnerable to ischemic reperfusion injury. Circ. Res. 86:264-269; 2000.

[39] Yoshida, T.; Maulik, N.; Engelman, R. M.; Ho, Y.-S.; Magnenat, J.-L.; Rousou, J. A.; Flack, J. E., 3rd; Deatron, D.; Das, D. K. Glutathione peroxidase knockout mice are susceptible to myocardial ischemia reperfusion injury. Circulation 96 (Suppl. II):216-220; 1996.

[40] Wang, P.; Chen, H.; Qin, H.; Sankarapandi, S.; Becher, M. W.; Wong, P. C.; Zweier, J. L. Overexpression of human copper, zinc-superoxide dismutase (SOD1) prevents postischemic injury. Proc. Natl. Acad. Sci. USA 95:4556-4560; 1998.

[41] Chen, Z.; Oberley, T. D.; Ho, Y.-S.; Chua, C. C.; Siu, B.; Hamdy, R. C.; Epstein, C. J.; Chua, B. H. L. Overexpression of CuZnSOD in coronary vascular cells attenuates myocardial ischemia/reperfusion injury. Free Radic. Biol. Med. 29:589-596; 2000.

[42] Yoshida, T.; Watanabe, M.; Engleman, D. T.; Engleman, R. M.; Schley, J.; Maulik, N.; Ho, Y.-S.; Oberley, T. D.; Das, D. K. Transgenic mice overexpressing glutathione peroxidase are resistant to myocardial ischemia reperfusion injury. J. Mol. Cell. Cardiol. 28:1759-1767; 1996.

[43] Crapo, J. D.; Barry, B. E.; Foscue, H. A.; Shelburne, J. Structural and biochemical changes in rat lungs occurring during exposure to lethal and adaptive doses of oxygen. Am. Rev. Respir. Dis. 122:123-143; 1980.

[44] Wispe, J. R.; Warner, B. B.; Clark, J. C.; Dey, C. R.; Neuman, J.; Glasser, S. W.; Crapo, J. D.; Chang, L. -Y.; Whitsett, J. A. Human Mn-superoxide dismutase in pulmonary epithelial cells of transgenic mice confers protection from oxygen injury. J. Biol. Chem. 267:23937-23941; 1992.

[45] Folz, R. J.; Abushamaa, A. M.; Suliman, H. B. Extracellular superoxide dismutase in the airways of transgenic mice reduces inflammation and attenuates lung toxicity following hyperoxia. J. Clin. Invest. 103: 1055-1066; 1999

[46] Wang, Y.; Phelan, S. A.; Manevich, Y.; Feinstein, S. I.; Fisher, A. B. 
Transgenic mice overexpressing peroxiredoxin 6 show increased resistance to lung injury in hyperoxia. Am. J. Respir. Cell Mol. Biol. 34: 481-486; 2006.

[47] Carlsson, L. M.; Jonsson, J.; Edlund, T.; Marklund, S. L. Mice lacking extracellular superoxide dismutase are more sensitive to hyperoxia. Proc. Natl. Acad. Sci. USA 92:6264-6268; 1995.

[48] Wang, Y.; Feinstein, S. I.; Manevich, Y.; Ho, Y.-S.; Fisher, A. B. Lung injury and mortality with hyperoxia are increased in peroxiredoxin 6 genetargeted mice. Free Radic. Biol. Med. 37:1736-1743; 2004.

[49] LeBras, M.; Clement, M. V.; Pervaiz, S.; Brenner, C. Reactive oxygen species and the mitochondrial signaling pathway of cell death. Histol. Histopathol. 20:205-219; 2005.

[50] Qanungo, S.; Starke, D. W.; Pai, H. V.; Mieyal, J. J.; Nieminen, A. L. Glutathione supplementation potentiates hypoxic apoptosis by Sglutathionylation of p65-NFkB. J. Biol. Chem. 282:18427-18436; 2007.

[51] Tu, B. P.; Weissman, J. S. Oxidative protein folding in eukaryotes: mechanisms and consequences. J. Cell Biol. 164:341-346; 2004.

[52] Thorpe, C.; Hoober, K. L.; Raje, S.; Glynn, N. M.; Burnside, J.; Turi, G. K.; Coppock, D. L. Sulfhydryl oxidases: emerging catalysts of protein disulfide bond formation in eukaryotes. Arch. Biochem. Biophys. 405: $1-12 ; 2002$.

[53] Lisowsky, T. ERV1 is involved in the cell-division cycle and the maintenance of mitochondrial genomes in Saccharomyces cerevisiae. Curr. Genet. 26:15-20; 1994.

[54] Lange, H.; Lisowsky, T.; Gerber, J.; Muhlenhoff, U.; Kispal, G.; Lill, R. An essential function of the mitochondrial sulfhydryl oxidase Erv1p/ALR in the maturation of cytosolic Fe/S proteins. EMBO Rep. 2:715-720; 2001.

[55] Matsui, M.; Oshima, M.; Oshima, H.; Takaku, K.; Maruyama, T.; Yodoi, J.; Taketo, M. M. Early embryonic lethality caused by targeted disruption of the mouse thioredoxin gene. Dev. Biol. 178:179-185; 1996.

[56] Nonn, L.; Williams, R. R.; Erickson, R. P.; Powis, G. The absence of mitochondrial thioredoxin 2 causes massive apoptosis, exencephaly, and early embryonic lethality in homozygous mice. Mol. Cell. Biol. 23: 916-922; 2003.

[57] Pineda-Molina, E.; Klatt, P.; Vazquez, J.; Marina, A.; de Lacoba, M. G.; Perez-Sala, D.; Lamas, S. Glutathionylation of the p50 subunit of NF- $\kappa$ B: a mechanism for redox-induced inhibition of DNA binding. Biochemistry 40:14134-14142; 2001.

[58] Bandyopadhyay, S.; Starke, D. W.; Mieyal, J. J.; Gronostajski, R. M.
Thioltransferase (glutaredoxin) reactivates the DNA-binding activity of oxidation-inactivated nuclear factor I. J. Biol. Chem. 273:392-397; 1998.

[59] Barrett, W. C.; DeGnore, J. P.; Konig, S.; Fales, H. M.; Keng, Y.; ZhongYin, Z.; Yim, M. B.; Chock, P. B. Regulation of PTP1B via glutathionylation of the active site cysteine 215. Biochemistry 38:6699-6705; 1999.

[60] Barrett, W. C.; DeGnore, J. P.; Keng, Y.; Zhang, Z.; Yim, M. B.; Chock, P. B. Roles of superoxide radical anion in signal transduction mediated by reversible regulation of protein-tyrosine phosphatase 1B. J. Biol. Chem. 274:34543-34546; 1999.

[61] Ward, N. E.; Stewart, J. R.; Ioannides, C. G.; O’Brian, C. A. Oxidantinduced $S$-glutathiolation inactivates protein kinase $\mathrm{C}-\alpha(\mathrm{PKC}-\alpha)$ : a potential mechanism of $\mathrm{PKC}$ isozyme regulation. Biochemistry 39: 10319-10329; 2000.

[62] Davis, D. A.; Newcomb, F. M.; Starke, D. W.; Ott, D. E.; Mieyal, J. J.; Yarchoan, R. Thioltransferase (glutaredoxin) is detected within HIV-1 and can regulate the activity of glutathionylated HIV-1 protease in vitro. J. Biol. Chem. 272:25935-25940; 1997.

[63] Dafre, A. L.; Sies, H.; Akerboom, T. Protein S-thiolation and regulation of microsomal glutathione transferase activity by the glutathione redox couple. Arch. Biochem. Biophys. 332:288-294; 1996.

[64] Adachi, T.; Pimentel, D. R.; Heibeck, T .; Hou, X.; Lee, Y. L.; Jiang, B.; Ido, Y; Cohen, R. A. S-glutathiolation of Ras mediates redox-sensitive signaling by angiotensin II in vascular smooth muscle cells. J. Biol. Chem. 279: 29857-29862; 2004.

[65] Lee, S. R.; Kwon, K. S.; Kim, S. R.; Rhee, S. G. Reversible inactivation of protein-tyrosine phosphatase $1 \mathrm{~B}$ in A431 cells stimulated with epidermal growth factor. J. Biol. Chem. 273:15366-15372; 1998.

[66] Reynaert, N. L.; van der Vliet, A.; Guala, A. S.; McGovern, T.; Hristova, M.; Pantano, C.; Heintz, N. H.; Heim, J.; Ho, Y.-S.; Matthews, D. E.; Wouters, E. F. M.; Janseen-Heininger, Y. M. W. Dynamic redox control of $\mathrm{NF}-\kappa \mathrm{B}$ through glutaredoxin-regulated S-glutathionylation of inhibitory кB kinase ß. Proc. Natl. Acad. Sci. USA 103:10386-10391; 2006.

[67] Pan, S.; Berk, B. C. Glutathiolation regulates tumor necrosis factor- $\alpha-$ induced caspase- 3 cleavage and apoptosis: key role for glutaredoxin in the death pathway. Circ. Res. 100:213-219; 2007.

[68] Wang, J.; Tekle, E.; Outrahim, H.; Mieyal, J. J.; Stadtman, E. R.; Chock, P. B. Stable and controllable RNA interference: investigating the physiological function of glutathionylated actin. Proc. Natl. Acad. Sci. USA 100:5103-5106; 2003. 